\title{
Why are migrants students better off in certain types of educational systems or schools than in others?
}

Citation for published version (APA):

Dronkers, J., van der Velden, R. K. W., \& Dunne, A. (2012). Why are migrants students better off in certain types of educational systems or schools than in others? European Educational Research Journal, 11(1), 11-44. https://doi.org/10.2304/eerj.2012.11.1.11

Document status and date:

Published: 01/01/2012

DOI:

10.2304/eerj.2012.11.1.11

Document Version:

Publisher's PDF, also known as Version of record

Document license:

Taverne

Please check the document version of this publication:

- A submitted manuscript is the version of the article upon submission and before peer-review. There can be important differences between the submitted version and the official published version of record.

People interested in the research are advised to contact the author for the final version of the publication, or visit the DOI to the publisher's website.

- The final author version and the galley proof are versions of the publication after peer review.

- The final published version features the final layout of the paper including the volume, issue and page numbers.

Link to publication

\footnotetext{
General rights rights.

- You may freely distribute the URL identifying the publication in the public portal. please follow below link for the End User Agreement:

www.umlib.nl/taverne-license

Take down policy

If you believe that this document breaches copyright please contact us at:

repository@maastrichtuniversity.nl

providing details and we will investigate your claim.
}

Copyright and moral rights for the publications made accessible in the public portal are retained by the authors and/or other copyright owners and it is a condition of accessing publications that users recognise and abide by the legal requirements associated with these

- Users may download and print one copy of any publication from the public portal for the purpose of private study or research.

- You may not further distribute the material or use it for any profit-making activity or commercial gain

If the publication is distributed under the terms of Article $25 \mathrm{fa}$ of the Dutch Copyright Act, indicated by the "Taverne" license above, 


\title{
Why are Migrant Students Better Off in Certain Types of Educational Systems or Schools than in Others?
}

\author{
JAAP DRONKERS \& ROLF VAN DER VELDEN \\ Maastricht University, The Netherlands \\ ALLISON DUNNE \\ GHK Consulting Ltd, Brussels, Belgium
}

\begin{abstract}
The main research question of this article is concerned with the combined estimation of the effects of educational systems, school composition, track level, and country of origin on the educational achievement of 15 -year-old migrant students. The authors focus specifically on the effects of socioeconomic and ethnic background on achievement scores and the extent to which these effects are affected by characteristics of the school, track, or educational system in which these students are enrolled. In doing so, they examine the 'sorting' mechanisms of schools and tracks in highly stratified, moderately stratified, and comprehensive education systems. They use data from the 2006 Programme for International Student Assessment (PISA) wave. Compared with previous research in this area, the article's main contribution is in explicitly including the tracks-within-school level as a separate unit of analysis, which leads to less biased results concerning the effects of educational system characteristics. The results highlight the importance of including factors of track level and school composition in the debate surrounding educational inequality of opportunity for students in different education contexts. The findings clearly indicate that analyses of the effects of educational system characteristics are flawed if the analysis only uses a country level and a student level and ignores the tracks-within-school-level characteristics. From a policy perspective, the most important finding is that educational systems are neither uniformly 'good' nor uniformly 'bad', but they can result in different consequences for different migrant groups. Some migrant groups are better off in comprehensive systems, while others are better off in moderately stratified systems.
\end{abstract}

\section{Introduction $^{[1]}$}

The low educational achievement level of migrant students in most western countries is a growing concern for policymakers for two reasons. First, high educational achieving is a prerequisite for successful integration into society and thus the best strategy to combat societal exclusion and discrimination of minority groups. Second, with the increasing globalisation of the economy, western countries face greater competition from rapidly developing countries such as China and India. Increasing the stock of human capital is seen as the best way to secure economic growth and prosperity (Hanushek \& Woessmann, 2010).

Many studies have shown that the low educational achievement of migrant students is partly explained by their lower socioeconomic status. But even controlling for this aspect, research still points toward a wide gap between native and migrant students in educational achievement. What is interesting from a policy perspective is that there is a substantial variation among migrant students themselves. This variation is linked to individual characteristics, such as the student's 
destination language, whether the student is a first- or second-generation migrant, age of migration, having one or two non-native parents, and so forth (Chiswick \& Miller, 1996, 2002).

This study focuses on the effects of certain education system characteristics on migrant students' performance. A study by the Organisation for Economic Co-operation and Development (OECD) (2007) showed that the more differentiated a country's educational system, the more native pupils outperform migrant pupils, even after taking into account social background characteristics. Ammermüller (2005), who used a more restricted measurement of differentiation (number of school types available), reached a more nuanced conclusion. The more different school types migrant students can choose from in secondary education, the better they perform on average. However, such a school system with choice between different school types enhances the negative effect of speaking that language at home.

Although these studies examine educational system effects on migrants, this is not the main focus of their analysis. Moreover, they lack an adequate design to study the effects of migrants' countries of origin and destination as these relate to their eventual educational achievement. The current article builds on earlier work by Levels et al (2008) and de Heus and Dronkers (2010a,b), which focuses on the influence of both societal and educational system characteristics of migrants' countries of origin and destination on their educational achievement. All of these studies use the cross-classified multilevel design first introduced by van Tubergen et al (2004). Instead of relying on observations of multiple-origin groups in a single destination or a single-origin group in multiple destinations, the authors proposed a combined method that allows a comparison of multiple origins in multiple destinations.[2] Levels et al (2008) show that the economic development level (gross domestic product per capita) of countries of origin negatively affects performance and that migrants originating from more politically stable countries perform better at school. Moreover, the higher educational performance of migrants' children living in traditional immigration societies can be fully explained by their favourable socioeconomic background composition. De Heus and Dronkers (2010b) found that migrant students performed on average better in comprehensive educational systems, but this was true only for children from privileged socioeconomic circumstances. They also showed that migrants from countries with an eastern religious affiliation perform better than migrants from Christian countries, while migrants from Islamic countries perform worse.

De Heus and Dronkers' (2010b) finding that migrant students on average perform better in comprehensive educational systems, but that this was only the case for privileged children, is not in line with earlier findings for natives (Breen \& Jonsson, 2000; Buchmann \& Hannum, 2001; OECD, 2005). These studies show that the effect of parental background on the achievement of their offspring is much lower in the comprehensive systems than in the highly stratified ones, which is the opposite of de Heus and Dronkers' (2010b) findings. Greater agreement can be observed regarding the overall educational system effect: both native and migrant students have, on average, higher scores in comprehensive educational systems compared with equivalent students in highly stratified educational systems. This means that countries in which students follow the same curriculum up to age 16 show higher results on achievement tests than countries in which students are directed into different secondary education tracks at very early ages.

A major problem with the above-mentioned studies (both for natives and migrants) is that they use a simple two-level model with a distinction between countries (origin and destination with societal and educational system characteristics) and students (with individual and family characteristics). Thus, they ignore the fact that there are more levels that affect student achievement. Students are nested in schools and within schools along different tracks, and all of these environments produce sources of variation in achievement levels.

Recently Dunne (2010) and Dronkers (2010a) introduced a three-level model: countries, schools, and students. They showed that school characteristics such as socioeconomic composition and ethnic diversity have substantial effects on achievement levels and also affect the relation between parental background and achievement. Moreover, these school characteristics seem to mediate some of the effects of educational system characteristics found earlier. They show that one of the reasons the relation between parental background and achievement is stronger in stratified educational systems is that these systems show stronger effects of the particular school a student attends. 
However, these two articles still do not include the track level as a separate level in the analysis. This is a serious omission if we consider stratified systems. It is unlikely that the results of stratified systems pertain to all of the tracks that can be distinguished. In fact, it might well be that the negative results of such systems only pertain to the lower or vocational tracks in these systems, while opposite results might be found for higher or more general tracks. In addition, they identified schools only by administrative unit and not by track level. This means that students in schools with different tracks are all regarded as being exposed to the same environment. Both omissions can produce flawed results, because track level has a strong effect on achievement. This might be even truer in the case of migrant students, as they are more heavily concentrated in the lower and vocational tracks.

The contribution of the current article is to improve the earlier work on two points: (1) by inclusion of track characteristics; and (2) by use of 'tracks-within-school' level, indexed by schoolidentification number, track level, and vocational orientation instead of by the administrative school level, and by defining school composition characteristics at this level.

The main research question of this article concerns the estimation of the effects of educational systems, school composition and track level on the educational achievement of 15year-old migrant students. We focus specifically on the effects of socioeconomic and ethnic background on achievement scores and consider the extent to which these effects are affected by characteristics of the school, track, or educational system in which these students are enrolled. In doing so, we examine the 'sorting' mechanisms of schools and tracks in highly stratified, moderately stratified, and comprehensive education systems.

We use the 2006 data wave of the Programme for International Student Assessment (PISA) (OECD, 2007). We include only those countries that provide information about the countries of birth of students and parents, so that we can identify the countries of origin. Therefore, the analysis is based on 8521 migrant students from 35 different countries of origin, living in 15 western destination countries. We use a four-level multilevel analysis with cross-classified origin and destination levels.

The results highlight the importance of including track level and school characteristics in the debate concerning educational inequality of opportunity for migrant students in different education contexts. The findings clearly indicate that the effects of educational system characteristics are flawed if the analysis uses only a country level and a student level and ignores the track-level characteristics. From a policy perspective, the most important finding is that educational systems are neither uniformly 'good' nor uniformly 'bad', but produce different consequences for different migrant groups. Some migrant groups are better off in comprehensive systems, while others are better off in moderately stratified systems.

The remainder of this article is organised as follows. In Section 2 we present an overview of the literature, followed by the hypotheses. Section 3 describes the data and operationalization of the variables. Section 4 describes the models, and Section 5 the main results. Section 6 concludes the article.

\section{Overview of the Literature ${ }^{[3]}$}

This article builds on two strands of research: general research on the inequality of educational opportunity, and specialised research that focuses on migrant student achievement. Previous comparative work focused on the reproduction of inequality and its relation to the degree of educational systems' stratification (Treiman \& Yip, 1989; Muller \& Karle, 1993; Shavit \& Blossfeld, 1993; Erikson \& Jonsson, 1996; Filmer \& Pritchett, 1999; Shavit et al, 2007; Pfeffer, 2008). Such reproduction is affected not only by educational system characteristics, but also by school characteristics, specifically the school's socioeconomic composition. However, the effect of the school's socioeconomic composition and its 'sorting' effect may vary across countries. One reason is that countries vary in the way they sort students during their secondary education instruction career. In this section, we will present an overview, first of the research on school factors, and subsequently on the institutional aspects of educational systems. Most of this literature was originally aimed at explaining the inequality of educational opportunity for natives. However, most of the reasoning can be applied to migrant students as well. Next, we will present specific research 
aimed at explaining migrant students' low achievement. It is the goal of this article to analyse the effects of both socioeconomic and ethnic background on migrant students' achievement scores and the extent to which these effects are affected by characteristics of the school, track, or educational system in which these students are enrolled.

\section{School Factors}

Since the Coleman Report (Coleman, 1966) in the United States and the Plowden Report (Peaker, 1971) in the United Kingdom, there has been debate on the relative importance of individual and school factors. These reports concluded that individual family background was more important than school factors in determining children's educational achievement. Since these reports were published, much research has concentrated on assessing the relative importance of individual versus school effects.

Borrowing from both the economic and organisational definitions of school effectiveness (Scheerens \& Bosker, 1997), we define schools as organisations that have particular processes in place to turn inputs into output. Inputs to a school include the students' prior characteristics, whereas outputs include student achievement. This transformative process that occurs within a school is composed of many factors, including teaching and learning methods, track choices, and organisational conditions that enable student learning. Earlier research revealed the importance of parental socioeconomic status on educational achievement (Blau \& Duncan, 1967; Jencks, 1972, Jencks et al., 1979, Hauser \& Sewell, 1986). This is true for migrant students as well (see de Heus \& Dronkers, 2010b). Later research also identified a link between differences in achievement scores and differences in the student body composition within the schools. They show that the school's mean socioeconomic background has an impact on student achievement over and above the effect of a student's individual socioeconomic background (Willms, 1986, 1992; Gamoran, 1992).

The OECD (2005) used the PISA 2000 data and applied a comparative perspective to examine the ways schools' socioeconomic composition affects achievement. In line with the research mentioned above, the report concluded that a school's average socioeconomic status had a statistically significant impact on student performance in reading literacy in all but four countries (Denmark, Finland, Iceland and Korea). Furthermore, school composition effects far outweighed the impact of other policy-amenable characteristics. Together with individual characteristics, a school's socioeconomic composition explained on average $69 \%$ of the school effects, compared with only $6 \%$ explained by policy-amenable school characteristics.

Thus, results from these studies show the strong link between a school's socioeconomic composition and student performance and achievement. However, studies have not shown whether this strong relationship between school composition and student achievement varies systematically across educational systems. Nevertheless, this concept seems plausible: Because countries vary in the way they sort their students for instruction, it follows that composition effects would vary across countries.

One important sorting mechanism is ability grouping or tracking. Many studies have found evidence that early division of students into ability groups or tracks increases inequality (Kerckhoff, 1986; Oakes et al, 1992; Gamoran, 2004). Research has explored achievement and inequality (Hargreaves, 1967; Dustmann, 2004; Ammermüller, 2005), in distinct tracks (Rosenbaum, 1976; Metz, 1978; Oakes, 1985; Gamoran, 1992; Gamoran et al, 1995), and placement into sets (or curricular differentiation; Lucas, 1999). Although these all represent different ways to differentiate students into ability groupings, all types of ability grouping result in a further enlargement of unequal educational opportunities. It is plausible that this applies even more strongly to migrants' children. Migrants' strategic knowledge concerning the educational system and how their offspring's educational choices will affect future educational careers is probably even less developed than that of native parents from low socioeconomic status.

Ability grouping is not just a school characteristic - most often it is a characteristic that directly results from the institutional design of the educational system. We will explore this in more detail in the section below. 
Stratification in Educational Systems

Spring (1976) has referred to educational institutions as society's 'sorting machine'. Organisational characteristics of schools and education systems effectively channel students into different educational paths and eventual life opportunities. All industrialised countries use organisational mechanisms to sort students into hierarchically arranged tracks, but these mechanisms vary both in their nature and in their timing. Hopper (1968, p. 30) argued that the structure of educational systems, especially those within industrial society, can be understood primarily in terms of the structure of their selection processes'. Systems can be identified as those that use separate school types to stratify students, those that have a high level of within-school/internal stratification without distinct school types, and systems that are comprehensive with low levels of within-school differentiation.

Early in the debate on the impact of how countries sort their students for instruction, Turner (1960) contributed to the discussion by characterising educational systems as being either 'contest mobility' or 'sponsored mobility' systems. He characterised comprehensive education systems as 'contest mobility', with the objective being to 'train as many as possible in the skills necessary for elite status so as to give everyone a chance to maintain competition at the highest pitch', and highly selective systems as 'sponsored mobility', with the objective being to 'indoctrinate elite culture in only those presumably who will enter the elite, lest there grow a dangerous number of "angry young men" who have elite skills without elite station' (Turner, 1960, p. 863).

Following this argument, many studies have investigated the degree of educational system stratification and its impact on the inequality of educational opportunity. Studies have revealed the variability across countries in the magnitude of family background effects on student outcomes (Buchmann \& Hannum, 2001) and how this is partly explained by the way in which a country sorts students to receive instruction (Hanushek \& Woessmann, 2006). Findings from Breen and Jonsson (2000), Mare (1993), and Shavit and Blossfeld (1993) suggest that comprehensive school reform in countries with previously highly stratified education systems reduced educational opportunity inequality. However, Breen and Jonsson (2005), in their review of inequality of opportunity in a comparative perspective, suggest the need to 'draw on evidence from more countries'.

The OECD (2005) report 'School Factors Related to Quality and Equity, Results from PISA 2000 ', which utilised data from PISA 2000, is one example from which evidence was drawn from a wide range of countries. The results indicate secondary education's structural relevance within each participating country. The report used age of selection as an indicator of institutional differentiation and considered its effect on student achievement. The results indicate that education systems with the lowest degree of differentiation achieved 'the highest mean student performance in reading literacy' (OECD, 2005. p. 62). Using the PISA 2000 data, Hanushek and Woessmann (2006) also found evidence that early tracking reduced mean performance. De Heus and Dronkers (2010b) report similar findings for migrant students. Migrants in a comprehensive educational system have on average a higher performance level than migrants in a highly stratified system.

The OECD report also indicated that in countries with early selection, the correlation between students' socioeconomic background and students' performance was stronger. These findings supported Kerckhoff's (1995) argument that the effects of family socioeconomic status on educational outcomes were stronger in highly stratified systems of education. Later analysis of PISA data by Marks et al (2006) confirmed this finding that countries with highly tracked systems tended to show stronger relationships between socioeconomic background and achievement. Horn (2009) also concluded that the early age of selection in some countries is closely linked with high inequality of opportunity. Pfeffer (2008, p. 556) looked at which nations were most successful in reducing the influence of family background on educational attainment by using the International Adult Literacy Survey and found that 'rigid education systems with dead-end educational pathways appear to be a hindrance to the equalisation of educational opportunities'. In such a system, parental strategic knowledge is crucial in helping children to make optimal choices. Migrants obviously lack much of this strategic knowledge. This presents no problem as long as no choices must be made, as is the case in a comprehensive system. It might not even be such a problem if the choices that must be made are clear-cut. Highly stratified systems with clear institutional borders between hierarchically ranked tracks probably present less of a problem for migrants than moderately stratified systems that have fuzzier borders. Many migrants feel a strong desire for 
upward mobility, and given the choice, will probably aim for the most prestigious tracks. In moderately stratified systems with forms of internal ability grouping, migrant parents might have more difficulty deciding which choice is optimal for their children.

\section{Results of Dunne (2010) and Dronkers (2010a)}

A major drawback of many of the previously mentioned studies is that they fail to combine the two lines of research - namely, the effects of (1) school factors and (2) educational system characteristics. They concentrate on either the effects of schools or the effects of educational systems. Both may produce flawed results, as the effects of schools may differ across different educational systems, and schools in fact produce part of the effects of educational systems. Recently, Dunne (2010) and Dronkers (2010a) made a major improvement to the methodology by introducing a three-level model in the analysis: countries, schools, and students.

Using PISA 2006 data, Dunne (2010) selected 23 countries that represent a wide range of comparable societies. The countries selected are Australia, Austria, Belgium, the Czech Republic, Canada, Denmark, Finland, Germany, Greece, Hungary, Ireland, Italy, Luxembourg, the Netherlands, New Zealand, Norway, Poland, Portugal, Spain, Sweden, Switzerland, the United Kingdom, and the United States.[4] She applied the three-level model (students, school, and countries) and distinguished between native and migrant students, with only two dummies to control for first and second generations.

She found that students in comprehensive schooling systems have higher overall average achievement, which appears to reflect the fact that students in low-socioeconomic-composition schools in comprehensive systems do not lose as much as do those in low-socioeconomiccomposition schools in highly stratified systems. Also, she found very little difference in the average achievement of students in highly stratified education systems and in moderately stratified education systems.

Inequality of opportunity at the individual level did not appear to be as Dunne expected from the evidence in previous research. Students from a higher socioeconomic background actually achieve less in highly stratified education systems than their counterparts in comprehensive systems, unless they are in high-socioeconomic-composition schools. Therefore, although inequality in educational opportunity is greater in highly stratified systems, it is mediated through school-composition effects. Still, there is a small individual social background effect within schools in highly stratified educational systems.

The degree of stratification of the educational system determines the extent to which the school's socioeconomic composition becomes a crucial element in student achievement. Placement into a higher socioeconomic school is a more significant condition for achievement in highly stratified systems. In comprehensive systems, achievement is very similar across schools with different socioeconomic compositions; therefore, there is an advantage for those in lowsocioeconomic-composition schools in this comprehensive system compared with those in lowsocioeconomic-composition schools in highly stratified education systems. On the other hand, individual socioeconomic background has a stronger effect on achievement within schools in comprehensive education systems.

Interestingly, although average student achievement varied greatly depending on the school's socioeconomic composition in highly stratified education systems, within schools in such systems the gap in achievement between students from the top and the bottom socioeconomic backgrounds was relatively narrow in comparison with students in comprehensive systems and moderately stratified systems. It appears that there is greater between-school equity within comprehensive education systems, but within-school equity is higher in highly stratified systems. Accordingly, it may be more difficult for students from a lower socioeconomic status to enter higher-socioeconomic-composition schools in highly stratified education systems, but once these students have entered such schools, the effect of their individual background does not hinder them unduly in their quest to achieve high scores.

Dronkers (2010a) also used the 2006 PISA data, based on a slightly different selection of countries from those that Dunne used. Dronkers included only those countries that provide information concerning the countries in which students and their parents were born, in order to 
properly identify the countries of origin. He showed that the socioeconomic composition of a school is of great importance. He found relatively few differences in the effect of the average parental educational level on students at school in the different education systems. In addition, he observed that students from non-Islamic Asia have an advantage when it comes to educational performance, compared with migrants from other countries of origin. Conversely, students from Islamic countries have a substantial disadvantage in educational performance compared with other migrants. Finally, he found that education systems do not always confer on native students the same type of positive or negative effects in terms of their achievement that they confer on students with a migrant background.

\section{Hypotheses}

As indicated above, the studies by Dunne (2010) and Dronkers (2010a) distinguish three levels in their analyses: countries, schools, and students. Although this is an improvement compared with the previous two-level studies, these studies are still biased, as they ignore one of the key levels the level of track. Track placement is one of the major characteristics affecting educationalopportunity inequality, serving as the 'sorting' mechanism of educational systems. It is therefore strange that this level has never been separately identified in previous analyses. Ignoring this level assumes that having a strongly stratified system will have the same effect on the students in the higher tracks as it has on those in the lower tracks. Similarly, ignoring this level assumes that school factors have the same effect on students of all the tracks within that school. Both assumptions are very unlikely. Our first three hypotheses can be seen as improving the hypotheses of Dunne (2010) by explicitly including the track level as an additional explanatory level. Unlike the analysis by Dunne (2010), these hypotheses are tested exclusively for the migrant students.[5] We have added two additional hypotheses, one concerning the possible different effect of educational systems on migrants and natives (based on the analysis of de Heus \& Dronkers, 2010b), and a second one about reproduction of educational inequality by the combination of individual parental class and school composition (Bourdieu \& Passeron, 1977).

Educational Systems; School Composition; Track; and

Parental Economic, Social, and Cultural Status (ESCS)

1. Track placement explains a substantial part of ESCS school composition effects on achievement but mostly in highly stratified educational systems, due to the institutionalised borders in these systems.

2. The positive effect of ESCS school composition on achievement is strongest in highly and moderately stratified systems, because ESCS school composition indicates both the level of the track and ESCS neighbourhood composition, while ESCS school composition in comprehensive educational systems indicates only differentiation in ESCS neighbourhood composition. But if one controls for track level, this stronger effect of ESCS school composition in highly and moderately stratified systems should disappear.

3. If one controls for track placement, the effect of individual ESCS on achievement is stronger in comprehensive systems: the lack of selection into hierarchical track levels forces parents of a higher socioeconomic status to use their cultural and social capital more to ensure sufficient school performance at age 15 .

\section{Migrant Students and Educational Systems}

4. Students with a migrant background experience the highest achievement in strongly stratified systems, because these provide them with clear information about their scholastic requirements, or in comprehensive educational systems, because these do not have institutionalised borders, which might preclude higher educational performance. 
Jaap Dronkers et al

Reproduction

5. The interactive effect of individual ESCS and ESCS school composition on achievement is positive and equal in all educational systems, because this combination of individual and school-composition ESCS indicates a higher level of unmeasured cultural and financial capital of both parents and school.

\section{Data and Operationalisation}

PISA 2006

Since 2000, the OECD has tri-annually conducted large-scale tests among 15-year-olds living in its member states and partner states in order to assess students' mathematical, reading and scientific literacy. The purpose of this test is to map the competences in the fields of mathematics, physics and reading at the end of the period of compulsory education (at the age of 15 or 16 in most western countries). We make use of the 2006 data. The PISA data for each participating country constitute a representative sample of the schools that teach 15-year-old students. Each school that has been selected tests a sample of all 15-year-olds, irrespective of their track or grade. In addition to educational performance, PISA also supplies information on a large number of individualbackground characteristics and school characteristics. The school principals provide details on a variety of school characteristics, such as student-teacher ratio, teacher shortages, and the location of the school. In the student questionnaires, students are asked for information on such elements as parents' educational level, the availability of resources at home, the language spoken at home, and the birth country of their parents. Considering that the information on the country of origin of both parents is crucial for our research question, we can only include countries that have actually provided information on these countries of origin. Although no fewer than 57 countries took part in PISA 2006, only the following 15 western countries had this information available: Australia, Austria, Belgium, Denmark, Finland, Germany, Greece, Latvia, Liechtenstein, Luxembourg, New Zealand, Norway, Portugal, Scotland, and Switzerland.[6] The selection leaves us with 8581 migrant students from 35 different countries of origin, living in 15 western destination countries.[7] Descriptive statistics can be found in Appendix A. For a detailed description of the data and performance scores of the students from the different countries of origin, we refer to previous publications (de Heus \& Dronkers, 2010b; Dronkers, 2010a).

\section{Schools and Tracks-within-Schools as Separate Units of Analysis}

The PISA data contain two cross-national indicators of the track the students are attending. The student was asked whether he or she is currently enrolled in a certain track at a certain level. This response was later recoded in the international format, distinguishing between general and vocational tracks on the one hand, and between lower and higher tracks on the other. This recoding by the national PISA data managers probably reflects the official national policy regarding the placement of different tracks into the international classification. For instance, we can see this clearly by comparing Finland and Scotland in Appendix B: all 15-year-old students in Finland attend lower general education, while all their counterparts in Scotland attend higher general education. The PISA data offer no other information to differentiate this coding any further to make it more comparable. The same held for Germany, where all students with a general track were coded at the lower level. However, the national specific programme code in the PISA data for Germany allowed us to distinguish between those students of general lower education with and without access to higher secondary education and between lower and higher vocational education (see Appendix B). For the other countries, this was not possible. As a general result, the level of 'noise' in the measurement of the real track level will increase and therefore underestimate the 'real' track-level effect. This should be kept in mind when looking at the results of track-level effects.[8]

Schools are the sampling unit in the PISA survey, but they often contain both general and vocational education and both levels within secondary education. The school level therefore reflects more the educational institution's administrative unit, while the combined two-track characteristics reflect more the daily reality of the teaching and learning environment, and also of 
the social intercourse between students and teachers. This daily life unit is a better indicator of the actual school environment of teaching and learning than the administrative unit. We call this the tracks-within-school level. We compute this level per country for each student by combining his or her school identification number, the kind of track he or she is following (vocational or general), and the track level (lower or higher). The result of this redefinition of school environment from an administrative unit into the daily life unit of teaching and learning is visible in Appendix B. For example, in Australia, 345 schools offered lower general education, 133 schools higher general education, and 10 schools higher vocational education for more than 5 students per school. In order to avoid extreme results for combinations with few cases, we deleted all combinations of school identification number, vocational or general education, and track level which had less than 6 students (natives and migrants) per school. This means that the analysis will be based on 8521 migrant students from 35 different countries of origin, living in 15 western destination countries.

\section{Dependent Variable: linguistic performance}

The dependent variable in this study is linguistic performance. Measuring linguistic skills accurately would make the test too long to be feasible. Hence, a large number of very similar but shorter tests were created. As such different tests can never have exactly the same degree of difficulty, item response modelling (IRM) was used to achieve comparable results between students who answered different variants of the same test. In this analysis, we averaged the five plausible values that were obtained from the IRM. The linguistic skills scores were standardised for the OECD countries using an average of 500 and a standard deviation of 100. Appendix $C$ shows the average literacy scores for migrant students for the origin and destination countries. Appendix E shows the outcomes if the dependent variable were mathematical literacy or science literacy. The results indicate that the conclusions do not change much if we were to take another dependent variable.

\section{Individual-Level Variables}

Parental ESCS. The ESCS index of the parents is a composite index created within the PISA dataset of the parents' occupational status, measured with the International Socio-economic Index of Occupational Status (ISEI) scale (Ganzeboom et al, 1992), the educational level of the parents, measured with the ISCED (International Standard Classification of Education) classification (UNESCO, 2006), and the presence of any material or cultural resources at the students' homes.[9] This combination of the parents' occupational status and educational level and the resources at home produces the strongest indicator of parental environment. We set the average of parental ESCS for each destination country to zero, to ensure that the comparisons for this item show the result for the average student in these countries.

Grade. Since not all students attend the same grade, we have included a variable to account for this. As a result of between-country variance in the way grades are constructed, we have standardised the grade around the modal grade in a country.

Female. We control for gender effects by using a dummy variable indicating whether a student is female (1) or male (0).

Regions of origin. Based on earlier analyses of PISA 2003 data (Levels \& Dronkers, 2008; Levels et al, 2008), we combined the countries of origin into five regions of origin in order to simplify the presentation of the analysis: 1. Eastern Europe (Albania, Belarus, Bosnia, Croatia, Czech Republic, Estonia, Hungary, Macedonia, Poland, Rumania, Russia, Serbia and Montenegro, Slovakia, Slovenia, Ukraine); 2. non-Islamic Asia (China, India, Korea, the Philippines, Vietnam); 3. Islamic countries (Albania, Bangladesh, Morocco, Pakistan, Turkey); 4. western OECD countries (Australia, Austria, Belgium, Denmark, France, Germany, Greece, Italy, Netherlands, New Zealand, Portugal, Spain, Sweden, Switzerland, United Kingdom, United States); 5. sub-Saharan Africa (Cape Verde, Congo, South Africa).[10] 
Second-generation migrant. In line with Rumbaut (2004), we have constructed migrant generation variables that combine information on the birth country of both parents and the student. Secondgeneration migrant children are those students for whom at least one parent was born abroad, but who have been born in the current country of destination themselves. First-generation migrant students have been born abroad themselves as well. A dummy indicates whether the student is second generation (1) or not (0).

One parent migrant, other parent native. A dummy variable was used to identify students who had one migrant and one native-born parent (1); students with two non-native parents represent the reference group (0).

Home language same as in destination country. We included a dummy variable to differentiate migrant children who speak one of their destination country's official languages at home (1) from children who speak a foreign language (0).

\section{Variables Measured at the Tracks-within-schools Level}

Vocational. A dummy variable indicates whether a student is currently enrolled in a (pre-) vocational (1) or general (0) type of education (ISCED classification).

Higher secondary. This dummy distinguishes the current track level within secondary education as higher secondary (1) or lower secondary (0).

Ethnic diversity. Using the numbers of students from all 35 countries of origin, we calculated the Herfindahl index of ethnic diversity per tracks-within-school (varying between 0 and 1).[11] All of the 35 countries of origin here represented a separate ethnic group; in addition, so did the native students.[12] The index should be interpreted as follows: the value 0 means that there was no ethnic diversity at all in the school, because all students came from the same country of origin. Values that approach 1 represent a very high degree of diversity: the students at that track-withinschool are equally recruited from all origin countries, including the home country. The Herfindahl index has been criticised for being 'colour-blind' (Voas et al, 2002; Stolle et al, 2008), which means that a school with $20 \%$ Turkish students and $80 \%$ native students obtains the same diversity score as a school with $20 \%$ native students and $80 \%$ Turkish students. The specific ethnic composition of the track-within-school is therefore also important, and hence we used appropriate indicators (see below).

ESCS diversity. In a similar way, we calculated the sociocultural diversity of the tracks-withinschools. Using the ESCS scores of both native and migrant parents, we divided these parental scores into five categories: the group with the lowest $10 \%$ scores; the $10-30 \%$ group; the $30-70 \%$ group; the $70-90 \%$ group; and the group with the highest $10 \%$ scores.[13] On the basis of these five categories, we calculated the Herfindahl index of sociocultural diversity (varying between 0 and 1).[14] The index should be interpreted as follows: A value 0 means that there is no diversity, because all parents of all students at that particular track-within-school are in the same ESCS category. A value approaching 1 indicates a very high level of diversity, indicating that the students are recruited equally from the five ESCS categories. As this Herfindahl index of sociocultural diversity is 'level-blind' and therefore insensitive to the average parental educational level, we have also added the average ESCS of a school to the analysis (see below).

Percentage of students from migrant regions. As indicated above, the countries of origin were combined into five categories in order to simplify the presentation of the analysis. For each track-withinschool, we calculated five indexes noting the percentage of students from each of the following five regions: Eastern Europe, non-Islamic Asia, Islamic countries, western OECD countries, and subSaharan Africa. These indexes are the necessary counterparts of the Herfindahl index of ethnic diversity, which after all is 'colour-blind'. Together, these indexes measure the combined effect of ethnic diversity and ethnic share. 
Average ESCS. In addition, we calculated the average parental ESCS per track-within-school. This index is the necessary counterpart of the Herfindahl index of sociocultural diversity, which is 'levelblind'. Together, these indexes measure the combined effect of sociocultural diversity and sociocultural share.

Selective admittance of students to the school is a scale in the PISA data based on principals' answers indicating whether admittance to their school was based on academic record or on recommendation. We divided the scale into three dummies: selective admittance, some selection, and no selection. Although these dummies are measured at the school level, we use them to control the amount of entrance selectivity at the track level.

Teacher shortage. The degree to which schools suffer a shortage of teachers is an index in the PISA data that indicates, according to the principals, to what extent education is hampered by a lack of qualified teachers for physics, mathematics, languages, or any other subjects. This index is based on answers given by the school principals. The average of this index for teacher shortage was set to zero for all destination countries and all students to ensure that the comparisons for this item show the result for the student in schools with an average shortage of teachers. Although this variable is measured at the school level, we will assume that it applies for each track within that school.

Student-staff ratio. The student-staff ratio (the number of students per member of staff per school) is based on the answer given by the school principals. The average for this ratio was set to zero for all destination countries and all students to ensure that the comparisons for this item show the result for the students in schools with an average student-staff ratio. Although this variable is measured at the school level, we will assume that it applies for each track within that school.

Urbanisation. Two dummies were constructed to indicate whether a school is located in a (large) city or in a rural area. Schools in an urbanised countryside or in (small) towns serve as the reference category.

School size. Number of students in the school. Although this variable is measured at the school level, we will assume that it applies for each track within that school.

Private/public. Educational systems differ in the shares of public and private schools and in the degree of state grants for these private scores. Two dummies were constructed to separate private dependent and private independent schools from public schools. These variables control for these system differences and for effectiveness of these school types (Dronkers \& Avram, 2010a, b).

\section{Variables Measured at the Country Level}

Stratification. To measure the level of differentiation of the educational system, we classified countries according to their stratification level. We define Austria, Switzerland, Germany and Liechtenstein as highly stratified systems; Belgium, Greece, Portugal and Luxembourg as moderately stratified systems; and Finland, Norway, Denmark, New Zealand, Australia, Scotland and Latvia as comprehensive educational systems that are hardly stratified. Our division is based on information on the first age at which students must choose amongst different educational types, the number of school types students can choose amongst, and the presence of more hidden types of ability grouping (OECD, 2007; de Heus \& Dronkers, 2010a). In the highly stratified countries, children can choose from at least 3 different educational types at age 10 (Germany, Austria), 11 (Liechtenstein), or 12 (Switzerland). In comprehensive systems, children are not tracked into different educational types before age 15 . We use dummy variables indicating whether countries have highly stratified, moderately stratified, or comprehensive educational systems.

Age of selection. Apart from these three dummies, age of selection is included in the analysis. 


\section{Models}

The results of the multilevel analyses are displayed in Table I. The analysis uses cross-classified multilevel regression analyses (Snijders \& Bosker, 1999; van Tubergen, 2005), because the countries of origin and destination cannot be structured hierarchically. Because of the maximum of five levels in MlWin, we could not use schools as a separate level above the tracks-within-schools level. A cross-classified analysis for migrant students needs, apart from the four levels for pupils, tracks, schools, and destination countries, two more levels: one for the origin countries and the other for the cross-classified identification. However, six levels are impossible in MlWin. Therefore, this multilevel analysis has three hierarchical levels: countries of origin/destination,; tracks-withinschools,; and students. School characteristics are thus transferred to the tracks-within-schools level.

\section{Models}

Model 0 is the empty model, which indicates how much variance is situated at the different levels. This model is important, because it shows that a relatively high amount of variance is related to the tracks-within-schools level. In addition, it shows that a greater amount of variance is related to the country of origin than to the country of destination, underlining the importance of including the countries of origin for explaining achievement differences among migrant students.

Model 1 includes the individual characteristics and the educational system characteristics, plus the interactions between the latter and parental ESCS. Thus, Model 1 resembles the standard approach to the analysis of educational systems effects, with country-level characteristics directly affecting educational performance. The only difference is that this model already contains the other distinguished levels, such as the tracks-within-schools level and the origin-country level. In order to estimate the relevance of our approach, we present in Appendix D the same Model 1 and the same data but with only two levels: students, and countries of origin and destination. The omission of the tracks-within-schools level increases the amount of variance at the individual level. In addition, the parameters of the individual variables tend to be stronger in the simple country-plus-student model than in a comparable four-level model. Especially, the effects of parental ESCS are greater in the simple approach than in the more correct four-level approach. The interactions between parental ESCS and educational systems characteristics are more or less the same in both approaches.

Model 2 adds social and ethnic composition variables at the tracks-within-school-level to the equation of Model 1 - namely, the shares of migrant students, the average parental ESCS, the ESCS and ethnic diversity, and two interaction terms between educational system and average parental ESCS. This model assumes that most of the variance at the tracks-within-schools level is related to the social and ethnic school composition and not to differences in the track's curriculum. Model 2 comes closest to the approach of Dunne (2010), who first introduced a school level between those of the educational system and the students.

In Model 3, we add to the equation of Model 1 the curriculum characteristics of the track (vocational orientation of the track, the level of the track, and two dummies regarding selective admittance), as well as the interaction between the level of the track and the stratification of the educational system. This model assumes that most of the variance at the tracks-within-schools level is related to differences in the track and not to the social and ethnic school composition.

Model 4 combines Models 2 and 3 by adding the social and ethnic composition variables as well as the curriculum characteristics of the track. The results for Model 4 show that both aspects (composition and curriculum characteristics of the track) must be included in the analysis in order to obtain a better fit with the data. Moreover, the parameters of the composition and curriculum variables are significant in this combined inclusion in the equation. This model best reflects our new approach of including curriculum characteristics next to student characteristics, social and ethnic school composition, and educational system characteristics.

In Models 5 and 6, we add more school variables and interactions to the equation of Model 4 to ensure that the results of Model 4 are not biased by the omission of these variables and interactions. These additions do not substantially alter the results of Model 4. 


\section{Main Results}

Table I presents the outcomes of the different models for the migrant students. Table II summarises some of the main results of the outcomes of Model 6 in Table I, especially the different effects of parental ESCS, ESCS school composition, and track level in the three educational systems. The baseline estimates for migrant students in Table II pertain to first-generation migrant students from western OECD countries whose home language is not the same as in the destination country and who have two non-native parents. The scores of the other migrant groups are obtained by simply looking at the estimates of Model 6 in Table I. This means that we assume that the scores of these groups are linearly related to the scores of the migrant students of the western OECD countries and that there is no interaction with the educational system characteristics. The scores for the students from Eastern Europe, non-Islamic Asia, Islamic countries and sub-Saharan African countries were obtained by changing the scores for the migrant students from western OECD countries by-8.2, $+18.6,-35.3$, and -15.0 respectively. This confirms the earlier findings by Dronkers (2010a) that students from non-Islamic Asia have an advantage when it comes to educational performance, compared with migrants from other origin countries. Students from Islamic countries have a substantial disadvantage in educational performance compared with other migrants, and these results hold even when one uses a model that includes track characteristics they score, on average (holding constant for other characteristics), half a standard deviation lower than all students from non-Islamic Asia. The scores of second-generation migrant students were obtained by increasing these scores by +9.3 ; for those who use the same language as the destination country, the scores were increased by +24.2 ; and for those with mixed parents, they were increased by +5.8 . This again underscores the importance of migrant children speaking the same language at home as the destination country's official language. To put it differently: migrant students coming from Islamic countries can make up their disadvantage compared with migrant students from western OECD countries by speaking the official destination country's language at home and by being second-generation instead of first-generation migrants.

\begin{tabular}{|c|c|c|c|c|c|c|c|}
\hline & M0 & M1 & M2 & M3 & M4 & M5 & M6 \\
\hline Constant & $\begin{array}{c}470.6 \\
(8.2)\end{array}$ & $\begin{array}{l}502.0 \\
(46.2)\end{array}$ & $\begin{array}{l}446.4 \\
(43.3)\end{array}$ & $\begin{array}{l}488.3 \\
(45.2)\end{array}$ & $\begin{array}{l}465.2 \\
(43.6)\end{array}$ & $\begin{array}{l}457.5 \\
(44.2)\end{array}$ & $\begin{array}{l}457.7 \\
(44.2)\end{array}$ \\
\hline \multicolumn{8}{|l|}{ Individual characteristics } \\
\hline Parental ESCS & & $\begin{array}{c}32.9^{\star \star} \\
(2.0)\end{array}$ & $\begin{array}{c}25.0^{\star \star} \\
(2.1)\end{array}$ & $\begin{array}{c}33.4^{\star \star} \\
(2.0)\end{array}$ & $\begin{array}{c}25.0^{\star \star} \\
(2.1)\end{array}$ & $\begin{array}{c}24.9^{\star \star} \\
(2.1)\end{array}$ & $\begin{array}{c}25.0^{\star \star} \\
(2.1)\end{array}$ \\
\hline $\begin{array}{l}\text { Eastern Europe origin (ref = } \\
\text { western OECD countries) }\end{array}$ & & $\begin{array}{l}-7.0 \\
(7.4)\end{array}$ & $\begin{array}{l}-10.1 \\
(7.1)\end{array}$ & $\begin{array}{l}-5.9 \\
(6.9)\end{array}$ & $\begin{array}{l}-6.8 \\
(6.8)\end{array}$ & $\begin{array}{l}-8.2 \\
(6.8)\end{array}$ & $\begin{array}{l}-8.2 \\
(6.8)\end{array}$ \\
\hline $\begin{array}{l}\text { Non-Islamic Asia origin }(\mathrm{ref}= \\
\text { western OECD countries) }\end{array}$ & & $\begin{array}{l}35.3^{\star \star} \\
(11.2)\end{array}$ & $\begin{array}{c}17.2 \\
(10.5)\end{array}$ & $\begin{array}{l}32.2^{\star \star} \\
(10.5)\end{array}$ & $\begin{array}{l}18.8^{\star} \\
(10.2)\end{array}$ & $\begin{array}{l}18.7^{\star} \\
(10.2)\end{array}$ & $\begin{array}{l}18.6^{\star} \\
(10.2)\end{array}$ \\
\hline $\begin{array}{l}\text { Islamic countries origin }(\mathrm{ref}= \\
\text { western OECD countries) }\end{array}$ & & $\begin{array}{c}-38.2^{\star \star} \\
(9.3)\end{array}$ & $\begin{array}{c}-35.7^{\star \star} \\
(8.8)\end{array}$ & $\begin{array}{c}-38.9^{\star \star} \\
(8.7)\end{array}$ & $\begin{array}{c}-35.1^{\star \star} \\
(8.4)\end{array}$ & $\begin{array}{c}-35.3^{\star \star} \\
(8.4)\end{array}$ & $\begin{array}{c}-35.3^{\star \star} \\
(8.4)\end{array}$ \\
\hline $\begin{array}{l}\text { Sub-Saharan Africa origin (ref }= \\
\text { western OECD countries) }\end{array}$ & & $\begin{array}{l}-22.7 \\
(16.0)\end{array}$ & $\begin{array}{l}-13.9 \\
(14.9)\end{array}$ & $\begin{array}{l}-25.6^{\star} \\
(14.9)\end{array}$ & $\begin{array}{l}-15.8 \\
(14.3)\end{array}$ & $\begin{array}{l}-15.0 \\
(14.2)\end{array}$ & $\begin{array}{l}-15.0 \\
(14.2)\end{array}$ \\
\hline Female & & $\begin{array}{c}30.6^{\star \star} \\
(1.7)\end{array}$ & $\begin{array}{l}29.9^{\star \star} \\
(1.6)\end{array}$ & $\begin{array}{c}28.5^{\star \star} \\
(1.7)\end{array}$ & $\begin{array}{c}28.5^{\star \star} \\
(1.6)\end{array}$ & $\begin{array}{c}28.6^{\star \star} \\
(1.6)\end{array}$ & $\begin{array}{c}28.6^{\star \star} \\
(1.6)\end{array}$ \\
\hline $\begin{array}{l}\text { Home language same as in } \\
\text { destination country }\end{array}$ & & $\begin{array}{c}26.1^{\star \star} \\
(2.3)\end{array}$ & $\begin{array}{l}24.3^{\star \star} \\
(2.2)\end{array}$ & $\begin{array}{c}25.5^{\star \star} \\
(2.2)\end{array}$ & $\begin{array}{c}24.2^{\star \star} \\
(2.2)\end{array}$ & $\begin{array}{l}24.2^{\star \star} \\
(2.2)\end{array}$ & $\begin{array}{c}24.2^{\star \star} \\
(2.2)\end{array}$ \\
\hline $\begin{array}{l}\text { One parent migrant, other parent } \\
\text { native }\end{array}$ & & $\begin{array}{c}4.8 \\
(4.0)\end{array}$ & $\begin{array}{c}6.1 \\
(3.8)\end{array}$ & $\begin{array}{c}4.8 \\
(3.9)\end{array}$ & $\begin{array}{c}5.4 \\
(3.8)\end{array}$ & $\begin{array}{c}5.8 \\
(3.8)\end{array}$ & $\begin{array}{c}5.8 \\
(3.8)\end{array}$ \\
\hline Second-generation migrant & & $\begin{array}{l}9.2^{\star \star} \\
(1.9)\end{array}$ & $\begin{array}{l}9.7^{\star \star} \\
(1.9)\end{array}$ & $\begin{array}{l}8.5^{\star \star} \\
(1.9)\end{array}$ & $\begin{array}{l}9.3^{\star \star} \\
(1.8)\end{array}$ & $\begin{array}{l}9.4^{\star \star} \\
(1.8)\end{array}$ & $\begin{array}{l}9.3^{\star \star} \\
(1.8)\end{array}$ \\
\hline $\begin{array}{l}\text { Grade (destination-country } \\
\text { centred) }\end{array}$ & & $\begin{array}{c}40.5^{\star \star} \\
(1.6)\end{array}$ & $\begin{array}{c}32.3^{\star \star} \\
(1.6)\end{array}$ & $\begin{array}{c}35.1^{\star \star} \\
(1.9)\end{array}$ & $\begin{array}{c}32.3^{\star \star} \\
(1.8)\end{array}$ & $\begin{array}{c}31.8^{\star \star} \\
(1.8)\end{array}$ & $\begin{array}{c}31.8^{\star \star} \\
(1.8)\end{array}$ \\
\hline $\begin{array}{l}\text { School-composition characteristics at } \\
\text { tracks-within-school }\end{array}$ & & & & & & & \\
\hline Average ESCS & & & $\begin{array}{c}49.8^{\star \star} \\
(4.8)\end{array}$ & & $\begin{array}{c}49.0^{\star \star} \\
(4.7)\end{array}$ & $\begin{array}{l}46.8^{\star \star} \\
(5.1)\end{array}$ & $\begin{array}{c}46.9^{\star \star} \\
(5.1)\end{array}$ \\
\hline $\begin{array}{l}\% \text { students from Eastern Europe } \\
\text { (ref }=\% \text { native students) }\end{array}$ & & & $\begin{array}{c}0.3 \\
(0.2)\end{array}$ & & $\begin{array}{c}0.3 \\
(0.2)\end{array}$ & $\begin{array}{l}0.4^{\star \star} \\
(0.2)\end{array}$ & $\begin{array}{l}0.4^{\star \star} \\
(0.2)\end{array}$ \\
\hline
\end{tabular}


$\%$ students from non-Islamic Asia (ref $=\%$ native students)

$\%$ students from Islamic countries (ref $=\%$ native students)

$\%$ students from western OECD

countries (ref $=\%$ native students)

$\%$ students from sub-Saharan

Africa (ref $=\%$ native students)

ESCS diversity

Ethnic diversity

Curriculum at tracks-within-school

Vocational $($ ref $=$ general $)$

Higher secondary $($ ref $=$ lower $)$

Selective admittance $(\mathrm{ref}=$ some selective admittance)

Non-selective admittance (ref $=$ some selective admittance)

School characteristics

Teacher shortage

Student/staff ratio

School in city (ref $=$ towns)

School in rural $(\mathrm{ref}=$ towns $)$

School size $e^{\star} 100$

Private dependent $(\mathrm{ref}=$ public

school)

Private independent $(\mathrm{ref}=$ public school)

Educational system characteristics

Strongly stratified (ref =

comprehensive)

Moderately stratified (ref =

comprehensive)

Age of selection

Interactions with educational systems

Parental ESCS ${ }^{\star}$ strongly stratified

Parental ESCS ${ }^{\star}$ moderately

stratified

Average ESCS ${ }^{\star}$ strongly stratified

Average ESCS ${ }^{\star}$ moderately

stratified

Higher secondary ${ }^{\star}$ strongly

stratified

Higher secondary` moderately

stratified

Reproduction

Parental ESCS ${ }^{\star}$ average ESCS

$1.4^{\star \star}$
$(0.2)$
0.2
$(0.1)$
-0.1
$(0.1)$
-0.2
$(0.4)$
$45.5^{\star \star}$
$(14.1)$
$-36.1^{\star \star}$

(11.4)

(0)

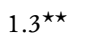

$1.2^{\star \star}$

$(0.2) \quad(0.2)$

$1.2^{\star \star}$

0.0

$(0.1)$

0.1

$(0.2)$

0.0

$(0.1)$

$(0.1)$

0.0

0.0

$\begin{array}{lll}(0.4) & (0.4) \quad(0.4)\end{array}$

$\begin{array}{lll}22.9 & 20.4 & 20.0\end{array}$

$(13.9) \quad(13.9) \quad(14.0)$
$-36.9 *$

$-36.9^{\star \star} \quad-40.1^{\star \star} \quad-40.3^{\star \star}$

$(11.0) \quad(11.2) \quad(11.2)$

$\begin{array}{llll}-85.8^{\star \star} & -54.5^{\star \star} & -54.1^{\star \star} & -54.1^{\star \star}\end{array}$

$\begin{array}{llll}(4.5) \quad(4.6) \quad(4.6) \quad(4.6) & 0.6\end{array}$

$\begin{array}{llll}-0.5 & 0.5 & -0.7 & -0.8\end{array}$

$\begin{array}{llll}(5.2) & (4.9) \quad(4.9) \quad(4.9)\end{array}$

$21.4^{\star \star} \quad 17.7^{\star \star} \quad 18.0^{\star \star} \quad 18.0^{\star \star}$

$\begin{array}{llll}(3.0) & (2.7) & (2.8) & (2.8)\end{array}$

$\begin{array}{llll}0.2 & 2.2 & 1.0 & 1.0\end{array}$

(2.6) (2.4) (2.4) (2.4)

$-1.6 \quad-1.6$

(1.1) (1.1)

$0.8^{\star \star} \quad 0.8^{\star \star}$

$(0.3) \quad(0.3)$

$\begin{array}{ll}2.7 & 2.7\end{array}$

(2.7) (2.7)

$2.7 \quad 2.7$

(2.7) (2.7)

$0.7^{\star \star} \quad 0.7^{\star \star}$

$(0.2) \quad(0.2)$

$\begin{array}{ll}-5.0 & -4.9\end{array}$

(3.7) (3.7)

$\begin{array}{ll}-6.6 & -6.4\end{array}$

(5.4) (5.4)

$-28.8^{\star} \quad-9.6$

$-41.1^{\star \star}$

$-15.4$

$-16.7 \quad-16.7$

(15.4) (14.4)

(15.0)

(14.4)

(14.5)

(14.5)

$-25.3^{\star} \quad-10.3$

$-41.1^{\star \star}$

$-20.1$

$-16.7 \quad-16.7$

$\begin{array}{lllll}(13.6) & (12.6) & (13.6) & (13.0) & (13.1)\end{array}$

$-2.1--2.1--2.3$

(2.8) (2.6)

(2.8)

(2.6)

(2.6)

(2.6)

$-16.1^{\star \star} \quad-16.5^{\star \star}$

$-18.5^{\star \star}$

$-16.5^{\star \star}$

$-16.4^{\star \star}-16.5^{\star \star}$

(2.4)

(2.5)

(2.3)

(2.4)

(2.4)

(2.5)

(3.2)

$-15.8^{\star \star}$

$-21.5^{\star \star}$

$16.3^{\star \star}$

$-16.3^{\star \star}$

$-16.5^{\star \star}$

$29.8^{\star \star}$

(5.9)

$18.4^{\star \star}$

$18.1 \star \star$

$19.6^{\star \star}$

(3.3)

$(5.9)-(6.1)-(6.2)$

$\begin{array}{lll}-11.8 & -10.8 \quad-11.0\end{array}$

(7.7)

$53.1^{\star \star} \quad 16.1^{\star \star} \quad 16.1^{\star \star} \quad 16.3^{\star \star}$

$\begin{array}{llll}(6.7) & (6.5) \quad(6.5) \quad(6.5)\end{array}$

$49.1^{\star \star} \quad 31.3^{\star \star} \quad 32.8^{\star \star} \quad 32.7^{\star \star}$

$\begin{array}{llll}(10.1) & (9.8) & (9.8) & (9.8)\end{array}$ 


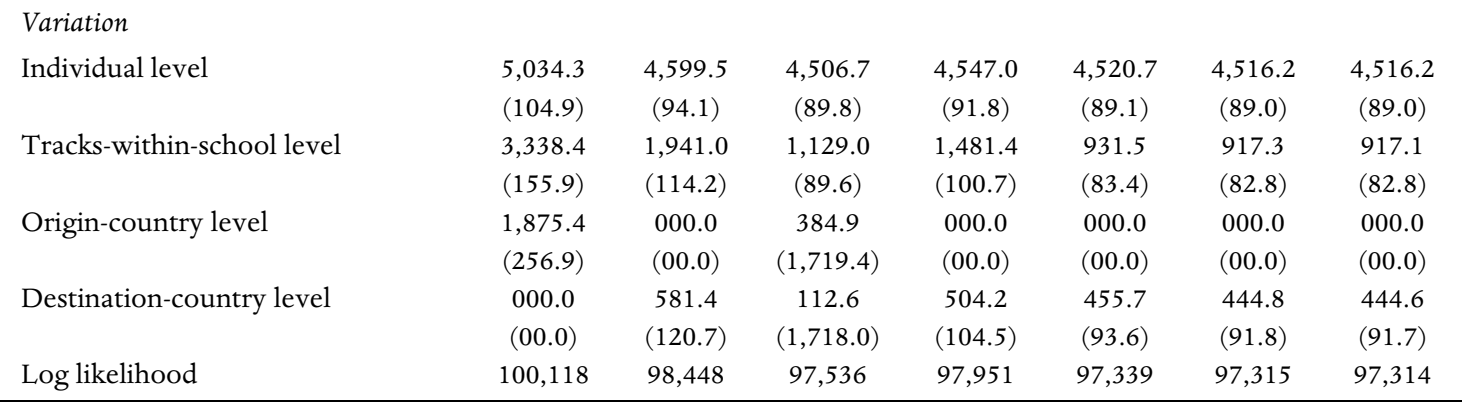

Table I. The effects of individual characteristics, track characteristics, school characteristics, and educational system characteristics on reading score of migrant students $(n$ origin $=35 ; n$ destination $=15 ; n$ tracks $=1,960 ; n$ students $=8521$; $\left.{ }^{\star} p<.05\right)$.

Source: PISA 2006; own computations.

\begin{tabular}{lccc}
\hline & Comprehensive & $\begin{array}{c}\text { Moderately } \\
\text { stratified }\end{array}$ & $\begin{array}{c}\text { Strongly } \\
\text { stratified }\end{array}$ \\
\hline Western OECD countries & 457.7 & 441.0 & 441.0 \\
Eastern Europe origin & -8.2 & -8.2 & -8.2 \\
Non-Islamic Asia origin & +18.6 & +18.6 & +18.6 \\
Islamic countries origin & -35.3 & -35.3 & -35.3 \\
Sub-Saharan Africa origin & -15.0 & -15.0 & -15.0 \\
Home language same as in destination & +24.2 & +24.2 & +24.2 \\
country & & +5.8 & +5.8 \\
One parent migrant, other parent native & +5.8 & +9.3 & +9.3 \\
Second-generation migrant & +9.3 & +8.5 & +8.5 \\
1 SD increase in Parental ESCS & +25.0 & +17.9 & +31.6 \\
1 SD increase in School ESCS & +23.5 & +31.9 & +15.5 \\
Track level higher instead of lower & -0.8 & -54.1 & -54.1 \\
Vocational instead of general & -54.1 & & \\
\hline
\end{tabular}

Table II. Summary of the different effects of parental ESCS, average ESCS school composition, and track level in different educational systems.

Source: PISA 2006; own computation. *Indicates effects that are allowed to differ between educational systems (interaction effects).

\section{The Differing Importance of Tracks in Different Educational Systems}

Our first hypothesis assumes that track levels explain a substantial part of the effect of ESCS school composition on achievement, but this applies mostly to highly stratified educational systems, due to the institutionalized borders in these systems. If we compare the log likelihood of Model 4 in Table I with that of Model 2 (only school composition) and Model 3 (only curriculum characteristics), we see that the log likelihood is lower in Model 4 than that in Models 2 and 3. This supports our first hypothesis, that track level explains a substantial part of the school composition effect and that the effects of curriculum characteristics should be distinguished from the effects of school composition. Compared with the log likelihood of Model 1 (only individual characteristics), however, the addition of school composition (Model 2) lowers the log likelihood more than the addition of curriculum characteristics (Model 3). This means that school composition can better explain variance in educational performance of migrant students than curriculum characteristics.

The interaction terms between track level and strongly or moderately stratified educational systems are positive and significant, in accordance with the first hypothesis. This means that for the higher level, less difference is found between educational systems. The main differences occur at the lower level. To illustrate this, for migrant students at the low level, the difference between moderate and comprehensive systems is 41.1 , to the advantage of the comprehensive system 
(Model 3 in Table I), while for the higher level, this has changed into a slight positive advantage for the moderate stratified systems, of $+7.5(-0.5,-41.1,+49.1)$.

\section{The Differing Importance of ESCS School Composition in Different Educational Systems}

Our second hypothesis assumes that the positive effect of ESCS school composition on achievement is strongest in highly and moderately stratified systems, because in these systems, ESCS school composition indicates both the curriculum level and the ESCS neighbourhood composition, while ESCS school composition in comprehensive educational systems indicates only differentiation in ESCS neighbourhood composition. Model 2 in Table I (only school composition) shows that ESCS school composition has strong effects on educational achievement in all systems, but that these are much stronger in the moderately and highly stratified systems than in the comprehensive systems (as indicated by positive effects of the interaction terms). However, after the inclusion of the curriculum variables (Model 4), these interaction effects remain significant only for the highly stratified systems. This indicates that part of the observed effect of the ESCS school composition is due to curriculum effects, in accordance with our second hypothesis. The sole remaining effect of ESCS school composition is for migrants in highly stratified systems.

\section{The Differing Importance of Individual ESCS in Different Educational Systems}

Our third hypothesis assumes that the effect of individual ESCS on achievement is stronger in comprehensive systems. The lack of selection into hierarchical track levels forces parents of a more privileged socioeconomic class to use more of their cultural and social capital to ensure sufficient school performance at the end of secondary school. Table I shows that individual ESCS has strong effects on educational achievement in comprehensive systems.[15]

Table II shows that the effects of individual ESCS are weaker in moderately and strongly stratified educational systems, in accordance with our third hypothesis and Dunne's (2010) results. Thus, Dunne's results cannot be explained by her omission of track level in her analyses.

\section{Migrants and Educational Systems}

Our fourth hypothesis assumes that students with a migrant background achieve the greatest gains in either strongly stratified systems, because these provide them with clear information about their scholastic requirements, or in comprehensive educational systems, because they do not have institutionalised curriculum borders that preclude high educational performance. The results of Table II support this expectation for the comprehensive educational systems, but not for strongly stratified systems. The achievement score of western OECD first-generation migrant students is highest in comprehensive systems (457.7), while their scores in the other two educational systems are slightly (but not significantly) lower (441.0). The same holds true for the other migrant groups.

Even so, these results hold true only for average students, not for various subgroups. Table III gives the estimated reading scores for students with the lowest and highest parental ESCS scores in schools with the lowest and highest average ESCS school composition in the three educational systems for the different immigration groups. As indicated above, the results pertain to firstgeneration migrant students whose home language is not the same as in the destination country and who have two non-native parents.[16] The results indicate that migrant students from high ESCS parents perform best in schools with a high ESCS composition in comprehensive systems. This result holds for all tracks (vocational lower, general lower, and general higher). These students perform poorest in schools with a low ESCS composition in strongly stratified systems. The situation is quite different for the students with low-ESCS parents. They perform best in schools with a high ESCS composition in strongly stratified systems, and they perform poorest in schools with a low ESCS composition in comprehensive systems. Again, this result holds for all tracks (vocational lower, general lower, and general higher). In other words, migrant students from different ESCS backgrounds do not experience the same educational opportunities and constraints in the different educational systems. A generic educational policy for these different groups might 
therefore produce different outcomes for students from low-ESCS parents in comparison with those from high-ESCS parents.

\begin{tabular}{|c|c|c|c|c|c|c|c|}
\hline & School & $\begin{array}{l}\text { Lowest } \\
\text { parent }\end{array}$ & $\begin{array}{l}\text { Highest } \\
\text { parent }\end{array}$ & $\begin{array}{l}\text { Lowest } \\
\text { parent }\end{array}$ & $\begin{array}{c}\text { Highest } \\
\text { parent }\end{array}$ & $\begin{array}{l}\text { Lowest } \\
\text { parent }\end{array}$ & $\begin{array}{c}\text { Highest } \\
\text { parent }\end{array}$ \\
\hline & $\begin{array}{c}\text { ESCS } \\
\text { composition }\end{array}$ & $\begin{array}{c}\text { ESCS \& } \\
\text { vocational } \\
\& \text { lower }\end{array}$ & $\begin{array}{c}\text { ESCS \& } \\
\text { vocational } \\
\& \text { lower }\end{array}$ & $\begin{array}{c}\text { ESCS \& } \\
\text { general \& } \\
\text { lower }\end{array}$ & $\begin{array}{c}\text { ESCS \& } \\
\text { general \& } \\
\text { lower }\end{array}$ & $\begin{array}{l}\text { ESCS \& } \\
\text { general \& } \\
\text { higher }\end{array}$ & $\begin{array}{c}\text { ESCS \& } \\
\text { general \& } \\
\text { higher }\end{array}$ \\
\hline \multicolumn{8}{|c|}{ Western OECD countries } \\
\hline \multirow[t]{2}{*}{ Comprehensive } & Lowest & 199 & 385 & 246 & 439 & 254 & 447 \\
\hline & Highest & 374 & 553 & 428 & 607 & 427 & 606 \\
\hline \multirow[t]{2}{*}{ Moderately } & Lowest & 259 & 323 & 307 & 378 & 346 & 416 \\
\hline & Highest & 412 & 469 & 466 & 523 & 498 & 555 \\
\hline \multirow[t]{2}{*}{ Strongly } & Lowest & 214 & 278 & 262 & 332 & 277 & 348 \\
\hline & Highest & 462 & 519 & 516 & 573 & 532 & 588 \\
\hline \multicolumn{8}{|c|}{ Eastern Europe origin } \\
\hline \multirow[t]{2}{*}{ Comprehensive } & Lowest & 191 & 377 & 238 & 431 & 246 & 439 \\
\hline & Highest & 366 & 545 & 420 & 599 & 419 & 598 \\
\hline \multirow[t]{2}{*}{ Moderately } & Lowest & 251 & 315 & 299 & 370 & 338 & 408 \\
\hline & Highest & 404 & 461 & 458 & 515 & 490 & 547 \\
\hline \multirow[t]{2}{*}{ Strongly } & Lowest & 206 & 270 & 254 & 324 & 269 & 340 \\
\hline & Highest & 454 & 511 & 508 & 565 & 524 & 580 \\
\hline \multicolumn{8}{|c|}{ Non-Islamic Asia origin } \\
\hline \multirow[t]{2}{*}{ Comprehensive } & Lowest & 218 & 404 & 265 & 458 & 273 & 466 \\
\hline & Highest & 393 & 572 & 447 & 626 & 446 & 625 \\
\hline \multirow[t]{2}{*}{ Moderately } & Lowest & 278 & 342 & 326 & 397 & 365 & 435 \\
\hline & Highest & 431 & 488 & 485 & 542 & 517 & 574 \\
\hline \multirow[t]{2}{*}{ Strongly } & Lowest & 233 & 297 & 281 & 351 & 296 & 367 \\
\hline & Highest & 481 & 538 & 535 & 592 & 551 & 607 \\
\hline \multicolumn{8}{|c|}{ Islamic countries origin } \\
\hline \multirow[t]{2}{*}{ Comprehensive } & Lowest & 164 & 350 & 211 & 404 & 219 & 412 \\
\hline & Highest & 339 & 518 & 393 & 572 & 392 & 571 \\
\hline \multirow[t]{2}{*}{ Moderately } & Lowest & 224 & 288 & 272 & 343 & 311 & 381 \\
\hline & Highest & 377 & 434 & 431 & 488 & 463 & 520 \\
\hline \multirow[t]{2}{*}{ Strongly } & Lowest & 179 & 243 & 227 & 297 & 242 & 313 \\
\hline & Highest & 427 & 484 & 481 & 538 & 497 & 553 \\
\hline \multicolumn{8}{|c|}{ Sub-Saharan Africa origin } \\
\hline \multirow[t]{2}{*}{ Comprehensive } & Lowest & 184 & 370 & 231 & 424 & 239 & 432 \\
\hline & Highest & 359 & 538 & 413 & 592 & 412 & 591 \\
\hline \multirow[t]{2}{*}{ Moderately } & Lowest & 244 & 308 & 292 & 363 & 331 & 401 \\
\hline & Highest & 397 & 454 & 451 & 508 & 483 & 540 \\
\hline \multirow[t]{2}{*}{ Strongly } & Lowest & 199 & 263 & 247 & 317 & 262 & 333 \\
\hline & Highest & 447 & 504 & 501 & 558 & 517 & 573 \\
\hline
\end{tabular}

Table III. Estimation of educational performance of first-generation migrants with lowest and highest parental ESCS, in schools with lowest and highest ESCS composition and with different track level in the three educational systems (comprehensive, moderately stratified and strongly stratified), based on Model 6 of Table I. 
Source: PISA 2006; own computation. The average scores of second-generation migrant students can be found by changing the scores by +9.3 , of those who use the same language as the destination country by +24.2 , and those with mixed parents by +5.8 .

\section{Reproduction}

Our fifth hypothesis assumes that the interaction effect of individual ESCS and ESCS school composition on achievement is positive and equal in all educational systems, because this combination of individual and school composition ESCS is an indicator of a higher level of unmeasured cultural and financial capital of both parents and schools. The basic idea is that individual and school ESCS reinforce each other, which will show up in a positive interaction term. Yet Model 6 in Table I shows that this hypothesis is not supported by our analysis. Although this result does not directly invalidate the reproduction theory, it does invalidate some of its strong claims, such as the reinforcement effect.

\section{Conclusions}

The Importance of Track Level

The first conclusion of this article is that an analysis of the effects of educational systems is flawed if it uses only a country level and a student level. Additional tracks-within-school levels are necessary in order to get reliable estimators of system and individual effects. Appendix D shows that the omission of the tracks-within-schools level increases the amount of variance at the individual level compared with four-level models. Further, the effects of the individual variables tend to be stronger in the model with only countries and students than in a comparable four-level model. Especially, the effects of parental ESCS are greater in the simple approach than those found in the more accurate four-level approach. The interactions between parental ESCS and educational system characteristics are more or less the same in both approaches. Finally, the fit of four-level models is far better than that of the simple models, indicating that the simple model gives a less adequate description of the relations between educational systems and educational achievement than does a four-level model. As a consequence, the outcomes of the simple country and student models, which remain dominant in the study of educational system effects, are flawed.

\section{Partial Confirmation of the Earlier Results by Dunne (2010)}

Our analysis confirmed the results of Dunne (2010) concerning the differential effects of parental background in different educational systems. The direct effect of parental ESCS is strongest in comprehensive systems, and weakest in moderately and strongly stratified educational systems, as well as after inclusion of the track level within the schools, the origin countries of migrant students, and the ethnic school diversity.

However, Dunne's results concerning the effects of average school ESCS are not confirmed. Without controlling for curriculum characteristics, average school ESCS effects are significantly greater in more stratified systems. After controlling for curriculum characteristics, however, average school ESCS effects in more stratified systems are no longer significant in the case of moderately stratified systems and significant only in the case of highly stratified systems.

\section{Different Effects of Curriculum}

The inclusion of the track level is necessary to avoid overestimation of the school-composition effect, especially in stratified educational systems. Our results show that the track-level effect is absent in comprehensive educational systems, while it is significant and positive in all stratified educational systems. In other words, curriculum level makes sense in stratified educational systems. Table II shows the consequences of this distinction between track levels. In a comprehensive system, the average reading score for migrant students from western OECD countries is 457.7 for students at the lower track level and 456.9 at the higher level. Note that no difference is observed between the higher and lower level in the comprehensive system, because 
countries code their systems differently from one another (see above). In moderately stratified systems, the scores are 441.0 and 472.9 , respectively, and in strongly stratified systems, 441.0 and 456.5. Attaining the higher track level is thus important for educational achievement in the stratified systems. Not taking the track level into account will give biased and flawed outcomes in analyses of effects of both educational systems and school composition. The table shows that no educational system can claim to have the best results for all students, but rather that results differ for the different track levels. For migrant students at the lower level, the comprehensive system is clearly superior to the two others. For students at the higher level, the situation is clearly different. Migrant students at this level realise the highest achievements in the moderately stratified systems.

\section{A Negative Effect of Vocational Education?}

Students with a vocational-oriented curriculum have lower reading scores than students in a general-oriented curriculum, and that lower score is not easily explained by the social and cultural characteristics of these students, their schools, or their educational systems. Despite all the control variables in Model 6 of Table I, students with a vocational-oriented curriculum score 54 points lower than students in a general-oriented curriculum. Appendix $\mathrm{E}$ shows that these differences in student scores are more or less the same in both vocational-oriented curricula and general-oriented curricula for maths and science. The fact that these differences are equivalent does not support the explanation that the difference is a consequence of choosing between more technical and cultural preferences and/or abilities of students. A possible explanation for these equivalent differences is that students in both general and vocational curricula differ strongly in terms of scholastic ability, and for that reason, they perform differently on all school tests, irrespective of the tests' content (Rindermann \& Ceci, 2009). Further analyses (not shown here) indicate that these lower scores of students with a vocational-oriented curriculum occur across all educational systems, but that in moderately stratified systems, these students score around 35 points lower than in the other systems.

\section{Direct and Indirect Effects of Parental Background}

The direct effects of parental ESCS on reading scores are smaller in both moderately and strongly stratified educational systems than they are in comprehensive systems. Yet the bivariate correlations between parental ESCS and reading scores are more or less equal in the three systems: 0.36, 0.35, and 0.39, respectively. The analogous partial correlations, controlled for ESCS school composition, are $0.23,0.14$, and 0.16 , respectively. This difference between the bivariate correlations and partial correlations can be partly explained by the different bivariate correlations between parental ESCS and ESCS school composition in the three educational systems: $0.47,0.48$, and 0.49. In other words, the influence of parental ESCS on the entrance selection of students into different tracks and schools is higher in stratified systems, because the long-term consequences of that selection are more severe than in comprehensive systems in which there is no selection. Without that entrance selection into different schools and tracks, the influence of parental ESCS is greater in comprehensive systems, because the social-background effect has not yet been transformed into different tracking or ability grouping.

\section{The Effects of Origin for Migrant Students and Educational Systems}

Estimates of educational system effects will be flawed if they fail to account for the different countries of origin of migrant students in different destination countries, and for the different levels of ethnic school diversity in different destination countries. By not accounting for migrant students' countries of origin, the positive effects of comprehensive systems will be overestimated, because the Scandinavian countries with comprehensive systems have relatively few migrant students originating from Islamic countries. Further, the negative effects of strongly stratified systems will be overestimated by the non-inclusion of origin countries, because Austria, Germany, Liechtenstein and Switzerland have relatively many migrant students originating from Islamic countries. These flaws are made in influential OECD reports such as Where Immigrant Students 
Succeed: a comparative review of performance and engagement in PISA 2003 (OECD, 2006), despite the fact that information on country of origin is already available in PISA 2003.

Migrant students originating from Islamic countries experience lower educational achievement than equivalent migrant children originating from other countries. Multiple explanations may be proposed: a discriminating attitude directed towards migrant students from Islamic countries; negative selectiveness of guest-worker programmes, wherein most guest workers in Europe come from Islamic countries, which affects the educational opportunities of their children; values and standards of the current Islam that are less suitable for success in modern societies (honour, unequal gender roles). André et al (2009) have used data from the European Social Survey (ESS) [17] to show that the degree of subjective feelings regarding discrimination against migrants in the European Union who practise an Islamic religion is not greater than that regarding discrimination against Greek Orthodox or Jewish believers. Dronkers and de Heus (2010a) have shown that the negative selectiveness towards migrants from turkey is not greater than that towards those from non-Islamic guest-worker countries (Yugoslavia, Italy and Portugal). Dronkers and Fleischmann (2010) have shown on the basis of the same ESS data that secondgeneration male Islam believers in Europe obtain a lower educational level than comparable migrants practising different religions. In addition, we have shown that it is practice of the Islamic faith by individual migrants that may lead to a lower educational level, not the fact that they have originated from a country with an Islamic majority.

Migrant students originating from non-Islamic Asian countries experience higher educational achievement than equivalent migrant children who originate from other countries. The standard explanations for this advantage (working harder for education; authoritarian education system; the 'ideal migrant') do not stand up empirically (see Dronkers $\&$ de Heus, 2010b). East Asia is therefore a much greater challenge for Europe in the education field than the United States (see also Dronkers, 2010b). These earlier results are not changed by the improved measurement of the concrete school environment and its characteristics by the tracks-within-school level.

\section{Caveats}

Finally, we want to issue two caveats in relation to our results. The first is a consequence of the need to control for migrant students' origin countries to obtain a more accurate estimate of educational system effects. Doing so requires the inclusion of more destination countries, both inside and outside Europe. Important countries to take into account, for instance, would be Canada, England, France and the United States. Only 16 of the OECD countries participating in PISA 2006 have asked for sufficiently detailed information about the country of birth of students and their parents, and very few additional countries have done that in PISA 2009. This is not only an obstacle in striving for the most accurate scientific analysis of migrant students' educational achievement, it is also socially and politically irresponsible to deny or ignore the importance of origin countries (see, for instance, European Commission, 2008).

The second caveat is that the quality of the measurement of the track level students attend must be improved, especially for countries with comprehensive educational systems (compare the levels of Scotland with those of Finland). Finally, the internal differentiation within schools (in terms of tracks, streams, etc.) should be measured better than is currently possible with the PISA data.

\section{Notes}

[1] More detailed information on the analysis contained in this article is provided in Dronkers et al (2011). Direct all correspondence to j.dronkers@maastrichtuniversity.nl

[2] It is important to distinguish both countries of destination and countries of origin. Omitting the latter from the analysis would give misleading results (Swedish and Russian migrants in Finland with a comprehensive system and Turkish and Yugoslav migrants in Germany with a strongly differentiated system cannot be treated as the same migrants, even after controlling for all measured background characteristics).

[3] This section is primarily based on Dunne (2010) and de Heus and Dronkers (2010a). 
[4] We could not use the same countries, because a number of them collected no information about the birth countries of the students and their parents.

[5] For a similar analysis for native students, see Dronkers et al (2011).

[6] The question on country of birth was not asked in a similar way in all countries. Most countries asked about the country of origin for the main migrant groups in the country concerned. In the German questionnaires, possible countries of origin were therefore Russia, the former Yugoslavia, Greece, Italy, Poland, and Turkey, whereas the Scottish questionnaire listed the options China, India, the Middle East, Africa, the Caribbean, and Europe. See also Levels et al (2008).

[7] Because PISA allows participating countries to determine the country-of-origin categories themselves, the level of detail differs among countries. As a result, the countries of origin that we have identified are dependent on the quality of the answer categories. To take this into consideration, we have compared the countries of origin that we defined with national statistics. In the case of Australia, Austria, Finland, Luxembourg, New Zealand, and Switzerland, the three main groups of migrants, as listed by their national statistics, match countries of origin that we found. In the case of Belgium, Germany, Liechtenstein, and Scotland, the two main groups, as indicated by their national statistics, match the countries of origin identified by us. In Greece, the main group of foreign origin consists of Albanians (42\% of all migrants, Eurostat, 2008), and this finding also matches our data. The main group of foreign origin in Latvia consists of Russians (35\% of all migrants, Eurostat, 2008), and this is also reflected in our data.

[8] We also checked whether centring the track level per country would solve this problem. The centred values are displayed in the last column of Appendix B, and the results of using centred values instead of the measured track levels are shown in Appendix F. In general, the results do not change much, which is the reason we decided to use the original track levels.

[9] The measure consists of the presence of a desk, a private room, a quiet place to study, a computer, educational software, Internet access, literature or poetry, art, books that may be of use when doing schoolwork, a dictionary, a dishwasher, and the presence of more than 100 books in the house.

[10] The number of migrants' children from Latin America is too small to justify a separate region.

[11] The Herfindahl index of ethnic diversity was calculated as follows: 1-([percentage of ethnic group 1$] 2$ + [percentage of ethnic group 2$] 2+\ldots+$ [percentage of ethnic group $n] 2)$.

[12] For the computation of the ethnic diversity, we used the countries of origin, not the regions of origin.

[13] The groups are defined as follows: (1) Less than 10\%: ESCS $<=-1.1$; (2) 10-30\%: $-1.0<$ ESCS $<=-0.4$; (3) 30-70\%: $-0.3<$ ESCS < = 0.6; (4) 70-90\%: $0.7<$ ESCS $<=1.2$; (5) more than $90 \%$ : ESCS $>=1.3$.

[14] The Herfindahl index of sociocultural diversity was calculated as follows: 1 -([percentage of parents from ESCS group 1]2 + [percentage of parents from ESCS group 2]2 $+\ldots+$ [percentage of parents from ESCS group 5]2).

[15] These individual ESCS effects tend to be a little bit smaller for migrant students than for the native students (see Dronkers et al, 2011). Individual ESCS of migrants might be a poorer indicator of their resources (ability, social, cultural) than for native parents. Further, the positive selection of migrants due to the obstacles and challenges of migration might explain this lower effect of individual ESCS on migrant students' achievement (Feliciano, 2005; Dronkers \& de Heus, 2010a).

[16] For an overview of the underlying parameters, see Appendix G.

[17] The ESS contains information about the respondents' individual religion.

\section{References}

Ammermüller, A. (2005) Educational Opportunities and the Role of Institutions, ZEW Discussion Papers, 44. Mannheim: Zentrum für Europäische Wirtschaftsforschung (ZEW).

André, S., Dronkers, J. \& Fleischmann, F. (2009) Verschillen in groepsdiscriminatie, zoals waargenomen door immigranten uit verschillende herkomstlanden in veertien lidstaten van de Europese Unie [Differences in in-group discrimination as perceived by immigrants from various countries of origin in fourteen member-states of the European Union], Mens en Maatschappij, 84, 448-482.

Blau, P.M. \& Duncan, O.D. (1967) The American Occupational Structure. New York: The Free Press.

Bourdieu, P. \& Passeron, J.C. (1977) Reproduction in Education, Society, and Culture. London: Sage. 
Breen, R. \& Jonsson, J.O. (2000) Analysing Educational Careers: a multinomial transition model, American Sociological Review, 65(5), 754-772. http: / / dx.doi.org/10.2307/2657545

Breen, R. \& Jonsson, J.O. (2005) Inequality of Opportunity in Comparative Perspective: recent research on educational attainment and social mobility, Annual Review of Sociology, 31, 223-243. http: / / dx.doi.org/10.1146/annurev.soc.31.041304.122232

Buchmann, C. \& Hannum, E. (2001) Education and Stratification in Developing Countries: a review of theories and research, Annual Review of Sociology, 27, 77-102. http: / / dx.doi.org/10.1146/annurev.soc.27.1.77

Chiswick, B.R. \& Miller, P.W. (1996) Ethnic Networks and Language Proficiency among Immigrants, Journal of Population Studies, 9, 19-35.

Chiswick, B.R. \& Miller, P.W. (2002) Immigrant Earnings: language skills, linguistic concentration, and the business cycle, Journal of Population Economics, 15, 31-57. http: / / dx.doi.org/10.1007/ PL00003838

Coleman, J.S. (1966) Equality of Educational Opportunity. Washington, DC: National Center for Educational Statistics (DHEW/OE).

de Heus, M. \& Dronkers, J. (2010a) De onderwijsprestaties van immigrantkinderen in 16 OECD-landen. De invloed van onderwijsstelsels en overige samenlevingskenmerken van zowel herkomst-als bestemmingslanden [The educational performance of immigrant children in 16 OECD-countries. The influence of educational systems and other societal features of both countries of origin and destination], Tijdschrift voor Sociologie, 31, 260-294.

de Heus, M. \& Dronkers, J. (2010b). The Educational Performance of Children of Immigrants in 16 OECD Countries: the influence of educational systems and other societal features of both countries of origin and destination. Unpublished Manuscript.

Dronkers J. (2010a) Positieve maar ook negatieve effecten van etnische diversiteit in scholen op onderwijsprestaties? Een empirische toets met internationale PISA-data [Positive but also negative effects of ethnic diversity in schools on educational achievement? An empirical test with cross-national PISA data], Tijdschrift voor Onderwijsrecht en Onderwijsbeleid, 6, 483-499. English-version paper presented at the conference 'Integration and Inequality in Educational Institutions' at the University of Bremen, 24-25 September, in Teerhof, Germany.

Dronkers, J. (2010b) Features of Educational Systems as Factors in the Creation of Unequal Educational Outcomes, in J. Dronkers (Ed.) Quality and Inequality of Education: cross-national perspectives, pp. 299-328. Dordrecht: Springer.

Dronkers, J. \& Avram, S. (2010a) A Cross-National Analysis of the Relations of School Choice and Effectiveness Differences between Private-Dependent and Public Schools, Educational Research and Evaluation, 16, 151-175. http:/ / dx.doi.org/10.1080/13803611.2010.484977

Dronkers, J. \& Avram, S. (2010b) A Cross-National Analysis of the Relations of School Choice and Effectiveness Differences between Private-Independent and Public Schools, Sociological Theory and Methods, 25, 183-206.

Dronkers, J. \& de Heus, M. (2010a) Negative Selectivity of Europe's Guest-Workers' Immigration? The Educational Achievement of Children of Immigrants Compared with the Educational Achievement of Native Children in their Origin Countries, in E. de Corte \& J. Fenstad (Eds) From Information to Knowledge; from Knowledge to Wisdom: challenges and changes facing higher education in the digital age, pp. 89-104. London: Portland Press.

Dronkers, J. \& de Heus, M. (2010b) The Higher Educational Achievement of Chinese Pupils, inside and outside of Asia: the higher transparency of Chinese numbers or a higher value of learning within Chinese culture? Unpublished manuscript.

Dronkers, J. \& Fleischmann, F. (2010) The Educational Attainment of Second Generation Immigrants from Different Countries of Origin in the EU-Member-States, in J. Dronkers (Ed.) Quality and Inequality of Education: cross-national perspectives. Dordrecht: Springer.

Dronkers, J., R. van der Velden \& A. Dunne (2011) The Effects of Educational Systems, School-Composition, Track-Level, Parental Background, and Immigrants' Origin on the Achievement of 15-Year-Old Native and Immigrant Students: a reanalysis of PISA 2006. ROA-RM-2011/6. Maastricht: Researchcentrum Onderwijs Arbeidsmarkt (ROA).

Dunne, A. (2010) Dividing Lines: examining the relative importance of between- and within-school differentiation during lower secondary education. $\mathrm{PhD}$ dissertation, European University Institute, Florence.

Dustmann, C. (2004) Parental Background, Secondary School Track Choice, and Wages, Oxford Economic Papers, 56(2), 209-230. http:/ / dx.doi.org/10.1093/oep/gpf048 
Erikson, R. \& Jonsson, J.O. (Eds) (1996) Can Education be Equalized? The Swedish Case in Comparative Perspective. Boulder, CO: Westview Press.

European Commission (2008) Migration and Mobility: challenges and opportunities for EU education systems. Green Paper. Brussels: European Commission.

Eurostat (2008) Europe in Figures. Eurostat Yearbook 2008. Luxembourg: Eurostat.

Feliciano, C. (2005) Educational Selectivity in US Immigration: how do immigrants compare to those left behind? Demography, 42, 131-152. http:/ / dx.doi.org/10.1353/dem.2005.0001

Filmer, D. \& Pritchett, L. (1999) The Effect of Household Wealth on Educational Attainment: evidence from 35 countries, Population and Development Review, 25, 85-120. http: / / dx.doi.org/10.1111/j.1728-4457.1999.00085.x

Gamoran, A. (1992) Social Factors in Education, in M. Alkin (Ed.) Encyclopedia of Educational Research, 6th edn, pp. 1222-1229. New York: Macmillan.

Gamoran, A. (2004) Classroom Organization and Instructional Quality, in H.J. Walberg, A.J. Reynolds \& M.C. Wang (Eds) Can Unlike Students Learn Together? Grade Retention, Tracking, and Grouping, pp. 141-155. Greenwich, CT: Information Age.

Gamoran, A., Nystrand, M., Berends, M. \& LePore, P.C. (1995) An Organisational Analysis of the Effects of Ability Grouping, American Educational Research Journal, 32(4), 687-715.

Ganzeboom, H.B.G., Graaf, P. de, Treiman, D.J. \& De Leeuw, J. (1992) A Standard International SocioEconomic Index of Occupational Status, Social Science Research, 21, 1-56. http: / / dx.doi.org/10.1016/0049-089X(92)90017-B

Hanushek, E.A. \& Woessmann, L. (2006) Does Educational Tracking Affect Performance and Inequality? Differences-in-Differences Evidence across Countries, Economic Journal, 116(510), C63. http: / / dx.doi.org/10.1111/j.1468-0297.2006.01076.x

Hanushek, E.A. \& Woessmann, L. (2010) The High Cost of Low Performance: the long-run economic impact of improving PISA outcomes. Paris: OECD.

Hargreaves, D. (1967) Social Relations in a Secondary School. London: Routledge \& Kegan Paul. http: / / dx.doi.org/10.4324/9780203001837

Hauser, R.M. \& Sewell, W.H. (1986) Family Effects in Simple Models of Education, Occupational Status, and Earnings: findings from the Wisconsin and Kalamazoo studies, Journal of Labor Economics, 4 July (Part 2), 83-115.

Hopper, E.I. (1968) A Typology for the Classification of Educational Systems, Sociology, 2, 29-46. http: / / dx.doi.org/10.1177/003803856800200103

Horn, D. (2009) Age of Selection Counts: a cross-country analysis of educational institutions, Educational Research and Evaluation, 15(4), 343-366. http: / / dx.doi.org/10.1080/13803610903087011

Jencks, C. (1972) Inequality: a reassessment of the effect of family and schooling in America. Harmondsworth: Penguin.

Jencks, C., Bartlett, S., Corcoran, M., et al (1979) Who Gets Ahead? The Determinants of Economic Success in America. New York: Basic Books.

Kerckhoff, A.C. (1986) Effects of Ability Groups in British Secondary Schools, American Sociological Review, 51, 842-858. http:/ / dx.doi.org/10.2307/2095371

Kerckhoff, A.C. (1995) Institutional Arrangements and Stratification Processes in Industrial Societies, Annual Review of Sociology, 15, 323-347. http:// dx.doi.org/10.1146/ annurev.so.21.080195.001543

Levels, M. \& Dronkers, J. (2008) Educational Performance of Native and Immigrant Children from Various Countries of Origin, Ethnic and Racial Studies, 31, 1404-1425. http: / / dx.doi.org/10.1080/01419870701682238

Levels, M., Dronkers, J. \& Kraaykamp, G. (2008) Immigrant Children’s Educational Achievement in Western Countries: origin, destination, and community effects on mathematical performance, American Sociological Review, 73, 835-853. http:/ / dx.doi.org/10.1177/000312240807300507

Lucas, S.R. (1999) Tracking Inequality: stratification and mobility in American high schools. New York: Teachers College Press.

Mare, R.D. (1993) Educational Stratification on Observed and Unobserved Components of Family Background, in Y. Shavit \& H.-P. Blossfeld (Eds) Persistent Inequality: changing educational attainment in thirteen countries, pp. 351-376. Boulder, CO: Westview Press. 
Marks, G.N., Creswell, J. \& Ainley, J. (2006) Explaining Socioeconomic Inequalities in Student Achievement: the role of home and school factors, Education Research and Evaluation, 12(2), 105-128. http: / / dx.doi.org/10.1080/13803610600587040

Metz, M.H. (1978) Classrooms and Corridors: the crisis of authority in desegregated secondary schools. Berkeley: University of California Press.

Muller, W. \& Karle, W. (1993) Social Selection in Educational Systems in Europe, European Sociological Review, 9, 1-23.

Oakes, J. (1985) Keeping Track: how schools structure inequality. New Haven, CT: Yale University Press.

Oakes, J., Gamoran, A. \& Page, R. (1992) Curriculum Differentiation, Opportunities, Outcomes and Meanings, in Y. Shavit \& W. Muller (Eds) From School to Work: a comparative study of educational qualifications and occupational destinations. Oxford: Oxford University Press.

Organisation for Economic Cooperation and Development (OECD) (2005) School Factors Related to Quality and Equity: results from PISA 2000. Paris: OECD.

Organisation for Economic Cooperation and Development (OECD) (2006) Where Immigrant Students Succeed: a comparative review of performance and engagement in PISA 2003. Paris: OECD.

Organisation for Economic Cooperation and Development (OECD) (2007) PISA 2006: science competencies for tomorrow's world. Paris: OECD.

Peaker, G.F. (1971) The Plowden Children Four Years Later. London: National Foundation for Education Research in England and Wales.

Pfeffer, P.T. (2008) Persistent Inequality in Educational Attainment and Its Institutional Context, European Sociological Review, 25(5), 543-565. http:/ / dx.doi.org/10.1093/esr/jcn026

Rindermann, H. \& Ceci, S.J. (2009) Educational Policy and Country Outcomes in International Cognitive Competence, Perspectives on Psychological Science, 4, 551-568.

http:/ / dx.doi.org/10.1111/j.1745-6924.2009.01165.x

Rosenbaum, J.E. (1976) Making Inequality: the hidden curriculum of high school tracking. New York: Wiley.

Rumbaut, R. (2004) Ages, Life Stages, and Generational Cohorts: decomposing the immigrant first and second generations in the United States, International Migration Review, 38(3), 1160-1205. http: / dx.doi.org/10.1111/j.1747-7379.2004.tb00232.x

Scheerens, J. \& Bosker, R.J. (1997) The Foundations of Educational Effectiveness. Oxford: Pergamon.

Shavit, Y., Arum, R. \& Gamoran, A. (Eds) (2007) Stratification in Higher Education: a comparative study. Stanford, CA: Stanford University Press.

Shavit, Y. \& Blossfeld, H.P. (1993) Persistent Inequality: changing educational attainment in thirteen countries. Boulder, CO: Westview Press.

Snijders, T.A.B. \& Bosker, R.J. (1999) Multilevel Analysis: an introduction to basic and advanced multilevel modelling. London: Sage.

Spring, J.H. (1976) The Sorting Machine: national educational policy since 1945. New York: McKay.

Stolle, D., Soraka, S. \& Johnston, R. (2008) When Does Diversity Erode Trust? Neighborhood Diversity, Interpersonal Trust and the Mediating Effect of Social Interactions, Political Studies, 56, 57-75. http:/ / dx.doi.org/10.1111/j.1467-9248.2007.00717.x

Treiman, D. J. \& Yip, K.-B. (1989) Educational and Occupational Attainment in 21 Countries, in M.L. Kohn (Ed.) Cross-national Research in Sociology. Newbury Park: Sage.

Turner, R.H. (1960) Sponsored and Contest Mobility and the School System, American Sociological Review, 25(6), 855-867. http: / / dx.doi.org/10.2307/ 2089982

UNESCO (2006) ISCED 1997: international standard classification of education (re-edition 2006). Paris: UNESCO.

van Tubergen, F. (2005) The Integration of Immigrants in Cross-National Perspective: origin, destination, and community effects. $\mathrm{PhD}$ dissertation, Universiteit Utrecht.

van Tubergen, F., Maas, I. \& Flap, H. (2004) The Economic Incorporation of Immigrants in 18 Western Societies: origin, destination and community effects, American Sociological Review, 69, 704-727. http: / / dx.doi.org/10.1177/000312240406900505

Voas, D., Crockett, A. \& Olson, D.V.A. (2002) Religious Pluralism and Participation: why previous research is wrong, American Sociological Review, 67, 212-230. http: / dx.doi.org/10.2307/3088893

Willms, J.D. (1986) Social Class Segregation and its Relationship to Pupils' Examination Results in Scotland, American Sociological Review, 51, 224-241. http: / / dx.doi.org/10.2307/2095518

Willms, J.D. (1992) Monitoring School Performance: a guide for educators. Washington, DC: Falmer Press. 
APPENDIX A

Table AI. Descriptive statistics for migrant students.

\begin{tabular}{|c|c|c|c|c|}
\hline & Min. & Max. & Mean & SD \\
\hline Science & 130.30 & 841.04 & 468.6504 & 103.36225 \\
\hline Maths & 154.92 & 790.07 & 479.8127 & 94.65479 \\
\hline Reading & 67.34 & 775.21 & 462.9986 & 102.80869 \\
\hline Average ESCS school & -2.07 & 1.64 & 0.0345 & 0.50160 \\
\hline Diversity ESCS & 0.00 & 0.79 & 0.6635 & 0.07145 \\
\hline Diversity ethnic & 0.03 & 0.84 & 0.4149 & 0.19621 \\
\hline$\%$ Western OECD & 0.00 & 100.00 & 14.7488 & 18.62151 \\
\hline \% Eastern Europe & 0.00 & 66.67 & 7.9945 & 12.80759 \\
\hline$\%$ Islamic countries & 0.00 & 92.31 & 5.9732 & 13.45775 \\
\hline$\%$ non-Islamic Asia & 0.00 & 87.50 & 2.5286 & 8.11845 \\
\hline$\%$ Sub-Saharan Africa & 0.00 & 33.33 & 1.1262 & 3.09810 \\
\hline Vocational orientation of school & 0.00 & 1.00 & 0.0817 & 0.27389 \\
\hline Level of track & 0.00 & 1.00 & 0.3441 & 0.47506 \\
\hline Level of track centred & -1.00 & 1.00 & -0.2881 & 0.90094 \\
\hline School size & 23 & 4468 & 845.77 & 629.165 \\
\hline Teacher-student ratio & 0.889 & 36.588 & 11.69007 & 3.942775 \\
\hline Teacher shortage & -1.0568 & 3.6194 & .287914 & 0.9777337 \\
\hline School in rural area & 0.00 & 1.00 & 0.2949 & 0.45603 \\
\hline School in city & 0.00 & 1.00 & 0.3717 & 0.48328 \\
\hline School admittance not selective & 0.00 & 1.00 & 0.2732 & 0.44011 \\
\hline School admittance selective & 0.00 & 1.00 & 0.2259 & 0.41509 \\
\hline Private independent school & 0.00 & 1.00 & 0.0501 & 0.21819 \\
\hline Private dependent school & 0.00 & 1.00 & 0.2402 & 0.42725 \\
\hline Public school & 0.00 & 1.00 & 0.7097 & 0.45395 \\
\hline Female & 0.00 & 1.00 & 0.5008 & 0.50003 \\
\hline ESCS & -4.4421 & 2.9709 & -0.232409 & 1.0159425 \\
\hline Migrant first generation & 0.00 & 1.00 & 0.4605 & 0.49847 \\
\hline Migrant second generation & 0.00 & 1.00 & 0.5003 & 0.50003 \\
\hline Mixed marriage & 0.00 & 1.00 & 0.0563 & 0.23057 \\
\hline Eastern Europe & 0.00 & 1.00 & 0.2746 & 0.44635 \\
\hline Western OECD & 0.00 & 1.00 & 0.4538 & 0.49789 \\
\hline Islamic country & 0.00 & 1.00 & 0.1620 & 0.36843 \\
\hline Non-Islamic Asia & 0.00 & 1.00 & 0.0908 & 0.28739 \\
\hline Sub-Saharan Africa & 0.00 & 1.00 & 0.0354 & 0.18490 \\
\hline Language of destination & 0.00 & 1.00 & 0.4995 & 0.50003 \\
\hline Grade (destination-country centred) & -2.00 & 3.00 & 0.3732 & 0.87115 \\
\hline Strongly stratified system & 0.00 & 1.00 & 0.5645 & 0.49585 \\
\hline Moderately stratified system & 0.00 & 1.00 & 0.1402 & 0.34726 \\
\hline Age of first selection & 10.00 & 16.00 & 13.2238 & 2.08364 \\
\hline Valid $n$ & 8521 & & & \\
\hline
\end{tabular}

Source: PISA 2006; own computations. 
Jaap Dronkers et al

APPENDIX B

Table AII. The number of schools and number of tracks-within-schools and the number of students in these tracks-within-schools (number of students of track-within-school >5).

\begin{tabular}{|c|c|c|c|c|c|c|}
\hline Country & Level & $\begin{array}{l}\text { No. of } \\
\text { tracks- } \\
\text { within- } \\
\text { schools }\end{array}$ & $\begin{array}{l}\text { Minimum no. } \\
\text { of students } \\
\text { per track- } \\
\text { within-school }\end{array}$ & $\begin{array}{l}\text { Maximum no. } \\
\text { of students } \\
\text { per track- } \\
\text { within-school }\end{array}$ & $\begin{array}{c}\text { Average no. } \\
\text { of students } \\
\text { per track- } \\
\text { within- } \\
\text { school } \\
\end{array}$ & $\begin{array}{c}\text { Level } \\
\text { centred per } \\
\text { country and } \\
\text { general/ } \\
\text { vocational }\end{array}$ \\
\hline \multirow[t]{3}{*}{ Australia } & lower general & 345 & 6 & 56 & 31.87 & -1 \\
\hline & higher general & 133 & 6 & 33 & 16.37 & +1 \\
\hline & higher vocational & 10 & 6 & 19 & 9.10 & 0 \\
\hline \multirow[t]{3}{*}{ Austria } & lower general & 11 & 6 & 26 & 9.64 & -1 \\
\hline & higher general & 88 & 6 & 35 & 29.51 & +1 \\
\hline & higher vocational & 79 & 8 & 38 & 26.06 & 0 \\
\hline \multirow[t]{4}{*}{ Belgium } & lower general & 8 & 6 & 18 & 8.50 & -1 \\
\hline & lower vocational & 12 & 6 & 29 & 14.33 & -1 \\
\hline & higher general & 250 & 6 & 161 & 26.76 & +1 \\
\hline & higher vocational & 113 & 6 & 66 & 12.64 & +1 \\
\hline \multirow[t]{3}{*}{ Switzerland } & lower general & 458 & 6 & 175 & 23.61 & -1 \\
\hline & higher general & 37 & 6 & 34 & 16.57 & +1 \\
\hline & higher vocational & 17 & 6 & 33 & 15.94 & 0 \\
\hline \multirow[t]{4}{*}{ Germany } & lower vocational & 3 & 9 & 17 & 10.00 & -1 \\
\hline & lower general & 118 & 9 & 25 & 20.20 & 0 \\
\hline & higher vocational & 5 & 8 & 25 & 15.40 & 0 \\
\hline & higher general & 96 & 6 & 25 & 20.59 & +1 \\
\hline \multirow[t]{2}{*}{ Denmark } & lower general & 201 & 6 & 28 & 21.64 & -1 \\
\hline & higher general & 2 & 6 & 7 & 6.50 & +1 \\
\hline Finland & lower general & 154 & 7 & 35 & 30.24 & 0 \\
\hline Scotland & higher general & 98 & 9 & 34 & 23.84 & 0 \\
\hline \multirow[t]{3}{*}{ Greece } & lower general & 11 & 6 & 27 & 11.64 & -1 \\
\hline & higher general & 125 & 8 & 35 & 30.66 & +1 \\
\hline & higher vocational & 29 & 7 & 34 & 23.93 & 0 \\
\hline \multirow[t]{2}{*}{ Liechtenstein } & lower general & 11 & 6 & 77 & 27.18 & -1 \\
\hline & higher general & 2 & 11 & 26 & 18.50 & +1 \\
\hline \multirow[t]{3}{*}{ Luxembourg } & lower general & 28 & 11 & 205 & 96.71 & -1 \\
\hline & higher general & 27 & 6 & 125 & 49.33 & +1 \\
\hline & higher vocational & 14 & 6 & 32 & 16.64 & 0 \\
\hline \multirow[t]{2}{*}{ Latvia } & lower general & 171 & 7 & 35 & 26.25 & 0 \\
\hline & higher vocational & 7 & 6 & 21 & 9.86 & 0 \\
\hline \multirow[t]{2}{*}{ Norway } & lower general & 191 & 6 & 30 & 23.28 & -1 \\
\hline & higher general & 1 & 7 & 7 & 7.00 & +1 \\
\hline \multirow[t]{2}{*}{ New Zealand } & lower general & 3 & 6 & 12 & 9.00 & -1 \\
\hline & higher general & 168 & 10 & 50 & 24.43 & +1 \\
\hline \multirow[t]{4}{*}{ Portugal } & lower general & 123 & 6 & 37 & 16.41 & -1 \\
\hline & lower vocational & 6 & 6 & 17 & 9.83 & -1 \\
\hline & higher general & 111 & 6 & 37 & 18.14 & +1 \\
\hline & higher vocational & 47 & 6 & 34 & 9.57 & +1 \\
\hline \multirow[t]{2}{*}{ Total natives } & Schools & 2861 & & & & \\
\hline & $\begin{array}{l}\text { Tracks-within- } \\
\text { schools }\end{array}$ & 3311 & & & & \\
\hline \multirow[t]{2}{*}{ Migrants } & Schools & 1756 & & & & \\
\hline & $\begin{array}{l}\text { Tracks-within- } \\
\text { schools }\end{array}$ & 1960 & & & & \\
\hline
\end{tabular}

Source: PISA 2006; own computations. The characteristics of schools and tracks-within-schools are based on all students, not just the migrant students. 
Achievement of Migrant Students

APPENDIX C

Table AIII. Average reading score of migrant students per country of destination and country of origin $(n=8521)$.

\begin{tabular}{|c|c|c|c|c|c|c|c|c|c|c|c|c|c|c|c|c|}
\hline \multirow{2}{*}{$\begin{array}{l}\text { Origin } \\
\text { countries }\end{array}$} & \multicolumn{16}{|c|}{ Destination countries } \\
\hline & $\mathrm{AU}$ & $\mathrm{AT}$ & $\mathrm{BE}$ & $\mathrm{CH}$ & $\mathrm{DE}$ & $\mathrm{DK}$ & EL & FI & LI & $\mathrm{LU}$ & LV & $\mathrm{NO}$ & $\mathrm{NZ}$ & PT & SC & Mean \\
\hline Albania & & 422 & & 353 & & & 433 & & 312 & & & & & & & 399 \\
\hline Australia & & & & & & & & & & & & & 551 & & & 551 \\
\hline Austria & & & & 478 & & & & & 534 & & & & & & & 501 \\
\hline Bangladesh & & & & & & & & & & & & & & & 453 & 453 \\
\hline Belarus & & & & & & & & & & & 486 & & & & & 486 \\
\hline Belgium & & & & & & & & & & 521 & & & & & & 521 \\
\hline Bosnia & & 457 & & & 459 & 445 & & & & & & & & & & 454 \\
\hline \multicolumn{17}{|l|}{ Herzegovina } \\
\hline Brazil & & & & & & & & & & & & & & 466 & & 466 \\
\hline Cape Verde & & & & & & & & & & 368 & & & & & & 368 \\
\hline China & 544 & 574 & & & & & & & & & & & 538 & 456 & 461 & 539 \\
\hline Congo & & & 437 & & & & & & & & & & & & & 437 \\
\hline Croatia & & 469 & & & 432 & & & & & & & & & & & 459 \\
\hline Czech & & 560 & & & & & & & & & & & & & & 560 \\
\hline \multicolumn{17}{|l|}{ Republic } \\
\hline Denmark & & & & & & & & & & & & 394 & & & & 394 \\
\hline Estonia & & & & & & & & 485 & & & & & & & & 485 \\
\hline France & & & 452 & 504 & & & & & 439 & 493 & & & & & & 485 \\
\hline Germany & & 525 & 502 & 530 & & & & & 529 & 520 & & & & & & 519 \\
\hline Greece & & & & & 412 & & & & & & & & & & & 412 \\
\hline Hungary & & 567 & & & & & & & & & & & & & & 567 \\
\hline India & 539 & & & & & & & & & & & & & & 494 & 538 \\
\hline Italy & & & & 451 & 410 & & & & 447 & 432 & & & & & & 443 \\
\hline Korea & 499 & & & & & & & & & & & & 512 & & & 506 \\
\hline Liechtenstein & & & & 464 & & & & & & & & & & & & 464 \\
\hline Macedonia & & 401 & & & 413 & & & & & & & & & & & 403 \\
\hline Morocco & & & 442 & & & & & & & & & & & & & 442 \\
\hline Netherlands & & & 489 & & & & & & & & & & & & & 489 \\
\hline New Zealand & 498 & & & & & & & & & & & & & & & 498 \\
\hline Pakistan & & & & & & 408 & & & & & & & & & 446 & 423 \\
\hline Philippines & 512 & & & & & & & & & & & & & & & 512 \\
\hline Poland & & 532 & 430 & & 488 & & & & & & & & & & & 469 \\
\hline Portugal & & & & 460 & & & & & 450 & 416 & & & & & & 426 \\
\hline Romania & & 444 & & & & & & & & & & & & & & 444 \\
\hline Russia & & & & & 462 & & & 562 & & & 463 & & & & & 472 \\
\hline Samoa & & & & & & & & & & & & & 443 & & & 443 \\
\hline Serbia & & 430 & & 427 & 397 & & & 413 & & & & & & & & 426 \\
\hline \multicolumn{17}{|l|}{ Montenegro } \\
\hline Slovakia & & 515 & & & & & & & & & & & & & & 515 \\
\hline Slovenia & & 428 & & & 447 & & & & & & & & & & & 432 \\
\hline South Africa & 527 & & & & & & & & & & & & & & & 527 \\
\hline Spain & & & & 467 & & & & & 517 & & & & & & & 469 \\
\hline Sweden & & & & & & & & 497 & & & & 451 & & & & 462 \\
\hline Switzerland & & & & & & & & & 501 & & & & & & & 501 \\
\hline Turkey & & 386 & 411 & 433 & 400 & 398 & & & 359 & & & & & & & 408 \\
\hline Ukraine & & & & & & & & & & & 447 & & & & & 447 \\
\hline United & 523 & & & & & & & & & & & & 554 & & & 532 \\
\hline \multicolumn{17}{|l|}{ Kingdom } \\
\hline United States & 559 & & & & & & & & & & & & & & & 559 \\
\hline Vietnam & 505 & & & & & & & & & & & & & & & 505 \\
\hline $\begin{array}{l}\text { Mean } \\
\text { migrants }\end{array}$ & 523 & 445 & 451 & 444 & 430 & 412 & 433 & 532 & 482 & 440 & 465 & 429 & 520 & 465 & 456 & 463 \\
\hline
\end{tabular}

Source: PISA 2006; own computations. 
Jaap Dronkers et al

APPENDIX D

Table AIV. The effects of individual characteristics and educational system characteristics (Model 6 in Table I) on reading scores of migrant in analyses with 4 or 2 levels.

\begin{tabular}{|c|c|c|c|}
\hline & $\begin{array}{l}\text { Model 1; } 4 \\
\text { levels }\end{array}$ & $\begin{array}{l}\text { Model 1;2 } \\
\text { levels }\end{array}$ & $\begin{array}{l}\text { Only ESCS \& } \\
\text { female }\end{array}$ \\
\hline Constant & $502.0(46.2)$ & $478.9(75.8)$ & $465.8(9.7)$ \\
\hline \multicolumn{4}{|l|}{ Individual characteristics } \\
\hline Parental ESCS & $32.9^{\star \star}(2.0)$ & $39.1^{\star \star}(2.0)$ & $40.7^{\star \star}(1.9)$ \\
\hline Eastern Europe origin (ref $=$ western OECD countries) & $-7.0(7.4)$ & $-9.8^{\star \star}(3.0)$ & - \\
\hline Non-Islamic Asia origin (ref $=$ western OECD countries $)$ & $35.3^{\star \star}(11.2)$ & $35.1^{\star \star}(3.9)$ & - \\
\hline Islamic countries origin ( $\mathrm{ref}=$ western $\mathrm{OECD}$ countries $)$ & $-38.2^{\star \star}(9.3)$ & $-33.4^{\star \star}(3.3)$ & - \\
\hline $\begin{array}{l}\text { Sub-Saharan Africa origin }(\mathrm{ref}=\text { western } \mathrm{OECD} \\
\text { countries) }\end{array}$ & $-22.7(16.0)$ & $-22.1^{\star \star}(5.0)$ & - \\
\hline Female & $30.6^{\star \star}(1.7)$ & $31.7^{\star \star}(1.8)$ & $36.2^{\star \star}(1.9)$ \\
\hline Home language same as in destination country & $26.1^{\star \star}(2.3)$ & $26.8^{\star \star}(2.2)$ & - \\
\hline One parent migrant, other parent native & $4.8(4.0)$ & $8.9^{\star \star}(4.1)$ & - \\
\hline Second-generation migrant & $9.2^{\star \star}(1.9)$ & $7.9^{\star \star}(2.0)$ & - \\
\hline Grade (destination-country centred) & $40.5^{\star \star}(1.6)$ & $46.0^{\star \star}(1.6)$ & - \\
\hline \multicolumn{4}{|l|}{ Educational system characteristics } \\
\hline Strongly stratified (ref = comprehensive) & $-28.8^{\star}(15.4)$ & $-19.4(24.4)$ & $-21.4(13.5)$ \\
\hline Moderately stratified (ref $=$ comprehensive $)$ & $-25.3^{\star}(13.6)$ & $-8.5(17.7)$ & $-32.2^{\star}(16.4)$ \\
\hline Age of selection & $-3.1(2.8)$ & $-2.2(4.7)$ & - \\
\hline \multicolumn{4}{|l|}{ Interactions with educational systems } \\
\hline Parental ESCS ${ }^{\star}$ strongly stratified & $-16.1^{\star \star}(2.4)$ & $-14.4^{\star \star}(2.3)$ & $-2.3(2.5)$ \\
\hline Parental ESCS ${ }^{\star}$ moderately stratified & $-14.1^{\star \star}(3.2)$ & $-16.2^{\star \star}(3.1)$ & $-5.9(3.3)$ \\
\hline \multicolumn{4}{|l|}{ Variation } \\
\hline Individual level & $4599.5(94.1)$ & $6687.1(102.5)$ & $7,762.6(119.1)$ \\
\hline Tracks-within-school level & $1941.0(114.2)$ & - & - \\
\hline School level & - & - & - \\
\hline Origin-country level & $0.0(0.0)$ & - & - \\
\hline Destination-country level & $581.4(120.7)$ & $439.2(176.6)$ & $458.3(195.9)$ \\
\hline Log likelihood & 98,448 & 99,279 & 100,549 \\
\hline
\end{tabular}

Source: PISA 2006; own computations.

${ }^{\star} p<.05$.

\section{APPENDIX E}

Table AV. The effects of individual characteristics, track characteristics, school characteristics and educational system characteristics (Model 6) on reading, maths and science scores of migrant students.

\begin{tabular}{lccc}
\hline & Reading & Maths & Science \\
\hline Constant & $457.7(44.2)$ & $502.9(38.4)$ & $553.6(44.2)$ \\
Individual characteristics & & & \\
Parental ESCS & $25.0^{\star \star}(2.1)$ & $22.4^{\star \star}(1.9)$ & $24.7^{\star \star}(2.1)$ \\
Eastern Europe origin (ref = western OECD countries) & $-8.2(6.8)$ & $-15.9^{\star \star}(5.9)$ & $-11.1(6.8)$ \\
Non-Islamic Asia origin (ref = western OECD countries) & $18.6^{\star}(10.2)$ & $27.7^{\star \star}(8.8)$ & $19.1(10.2)$ \\
Islamic countries origin (ref = western OECD countries) & $-35.3^{\star \star}(8.4)$ & $-31.9^{\star \star}(7.2)$ & $-36.0^{\star \star}(8.4)$ \\
Sub-Saharan Africa origin (ref = western OECD countries) & $-15.0(14.2)$ & $-18.1(12.1)$ & $-14.3(14.3)$ \\
Female & $28.6^{\star \star}(1.6)$ & $-20.7^{\star \star}(1.5)$ & $-9.9^{\star \star}(1.6)$ \\
Home language same as in destination country & $24.2^{\star \star}(2.2)$ & $16.2^{\star \star}(2.0)$ & $23.0^{\star \star}(2.2)$
\end{tabular}


One parent migrant, other parent native

Second-generation migrant

Grade (destination-country centred)

School-composition characteristics at tracks-within-school

\section{Average ESCS}

$\%$ students from Eastern Europe (ref $=\%$ native students)

$\%$ students from non-Islamic Asia (ref $=\%$ native students)

$\%$ students from Islamic countries ( $\mathrm{ref}=\%$ native students)

$\%$ students from western OECD countries (ref $=\%$ native

students)

$\%$ students from Sub-Saharan Africa ( $(\mathrm{ref}=\%$ native students)

ESCS diversity

Ethnic diversity

Curriculum at tracks-within-school

Vocational $($ ref $=$ general $)$

Higher secondary (ref = lower)

Selective admittance ( $\mathrm{ref}=$ some selective admittance)

Non-selective admittance ( $\mathrm{ref}=$ some selective admittance)

School characteristics

Teacher shortage

Student/staff ratio

School in city (ref $=$ towns)

School in rural (ref $=$ towns)

School size ${ }^{\star} 100$

Private dependent $(\mathrm{ref}=$ public school $)$

Private independent (ref = public school)

Educational system characteristics

Strongly stratified (ref $=$ comprehensive)

Moderately stratified (ref $=$ comprehensive)

Age of selection

Interactions with educational systems

Parental ESCS ${ }^{\star}$ strongly stratified

Parental ESCS ${ }^{\star}$ moderately stratified

Average $\mathrm{ESCS}^{\star}$ strongly stratified

Average $\mathrm{ESCS}^{\star}$ moderately stratified

Higher secondary ${ }^{\star}$ strongly stratified

Higher secondary ${ }^{\star}$ moderately stratified

Reproduction

Parental ESCS ${ }^{\star}$ average ESCS

Variation

Individual level

Tracks-within-school level

School level

Origin-country level

Destination-country level

Log likelihood

$\begin{array}{ccc}5.8(3.8) & 5.9(3.5) & 10.2^{\star \star}(3.8) \\ 9.3^{\star \star}(1.8) & 8.0^{\star \star}(1.7) & 7.5^{\star \star}(1.9) \\ 31.8^{\star \star}(1.8) & 33.6^{\star \star}(1.7) & 31.7^{\star \star}(1.8)\end{array}$

$46.9^{\star \star}(5.1) \quad 43.5^{\star \star}(4.7) \quad 50.5^{\star \star}(5.1)$

$0.4^{\star \star}(0.2) \quad 0.3^{\star \star}(0.1) \quad 0.3^{\star}(0.2)$

$1.2^{\star \star}(0.2) \quad 1.2^{\star \star}(0.2) \quad 1.3^{\star \star}(0.2)$

$0.1(0.1) \quad 0.1(0.1) \quad 0.0(0.1)$

$0.0(0.1) \quad 0.0(0.1) \quad 0.2^{\star}(0.1)$

$\begin{array}{lll}-0.2(0.4) & 0.0(0.4) & -0.2(0.4)\end{array}$

$20.0(14.0) \quad 17.0(13.0) \quad 23.1(13.9)$

$-40.3^{\star \star}(11.2) \quad-34.4^{\star \star}(10.4) \quad-42.6^{\star \star}(11.0)$

$-54.1^{\star \star}(4.6) \quad-52.4^{\star \star}(4.3) \quad-50.1^{\star \star}(4.5)$

$\begin{array}{lll}-0.8(4.9) & -0.4(4.5) & 0.9(4.9)\end{array}$

$18.0^{\star \star}(2.8) \quad 18.9^{\star \star}(2.6) \quad 19.5^{\star \star}(2.7)$

$1.0(2.4) \quad 1.2(2.2) \quad 0.8(2.4)$

$-1.6(1.1) \quad-2.6^{\star \star}(1.0) \quad-1.5(1.1)$

$0.8^{\star \star}(0.3) \quad 0.3(0.3) \quad 0.3(0.3)$

$\begin{array}{lll}2.7(2.7) & -0.3(2.5) & 1.5(2.7)\end{array}$

$2.7(2.7) \quad 4.1(2.5) \quad 5.9^{\star \star}(2.6)$

$0.7^{\star \star}(0.2) \quad 0.7^{\star \star}(0.2) \quad 0.6^{\star \star}(0.2)$

$-4.9(3.7) \quad-10.7^{\star \star}(3.4) \quad-6.0^{\star}(3.6)$

$-6.4(5.4) \quad-10.3^{\star \star}(5.0) \quad-4.5(5.4)$

$-16.7(14.5) \quad-17.0(12.5) \quad-43.9^{\star \star}(14.5)$

$-16.7(13.1) \quad-16.0(11.4) \quad-28.2^{\star \star}(13.1)$

$-2.3(2.6) \quad-1.8(2.3) \quad-6.1^{\star \star}(2.6)$

$-16.5^{\star \star}(2.5) \quad-14.0^{\star \star}(2.3) \quad-14.3^{\star \star}(2.5)$

$-16.5^{\star \star}(3.3) \quad-17.3^{\star \star}(3.1) \quad-15.9^{\star \star}(3.3)$

$19.5^{\star \star}(6.2) \quad 18.4^{\star \star}(5.7) \quad 10.1(6.1)$

$-11.0(8.3) \quad-5.8(7.7) \quad-17.7^{\star \star}(8.3)$

$16.3^{\star \star}(6.5) \quad 11.4^{\star}(6.0) \quad 13.0^{\star \star}(6.4)$

$32.7^{\star \star}(9.8) \quad 27.8^{\star \star}(9.0) \quad 20.3^{\star \star}(9.7)$

$-0.5(1.8) \quad 3.5^{\star \star}(1.6) \quad 3.1^{\star \star}(1.8)$

$4,516.2(89.0) \quad 3,904.3(76.9) \quad 4,663.7(91.0)$

$917.1(82.8) \quad 792.0(71.6) \quad 793.2(80.2)$

$0.0(0.0) \quad 0.0(0.0) \quad 291.4(1640.2)$

$444.6(91.7) \quad 312.0(67.0) \quad 159.0(1639.6)$

$97,314 \quad 96,060 \quad 97,415$

Source: PISA 2006; own computations. 
Jaap Dronkers et al

\section{APPENDIX F}

Table AVI. The effects of individual characteristics and educational system characteristics (Model 6) on reading scores of migrant students with the measured and country-centred track level.

\begin{tabular}{|c|c|c|}
\hline & Measured track level & Centred track level \\
\hline Constant & $457.7(44.2)$ & $457.2(45.6)$ \\
\hline \multicolumn{3}{|l|}{ Individual characteristics } \\
\hline Parental ESCS & $25.0^{\star \star}(2.1)$ & $24.9^{\star \star}(2.1)$ \\
\hline Eastern Europe origin (ref = western OECD countries) & $-8.2(6.8)$ & $-6.9(7.0)$ \\
\hline Non-Islamic Asia origin (ref = western OECD countries) & $18.6^{\star}(10.2)$ & $19.6^{\star}(10.5)$ \\
\hline Islamic countries origin ( $\mathrm{ref}=$ western $\mathrm{OECD}$ countries $)$ & $-35.3^{\star \star}(8.4)$ & $-35.2^{\star \star}(8.6)$ \\
\hline Sub-Saharan Africa origin (ref = western OECD countries) & $-15.0(14.2)$ & $-14.6(14.7)$ \\
\hline Female & $28.6^{\star \star}(1.6)$ & $28.6^{\star \star}(1.6)$ \\
\hline Home language same as in destination country & $24.2^{\star \star}(2.2)$ & $24.2^{\star \star}(2.2)$ \\
\hline One parent migrant, other parent native & $5.8(3.8)$ & $5.7(3.8)$ \\
\hline Second-generation migrant & $9.3^{\star \star}(1.8)$ & $9.4^{\star \star}(1.8)$ \\
\hline Grade (destination-country centred) & $31.8^{\star \star}(1.8)$ & $33.0^{\star \star}(1.8)$ \\
\hline \multicolumn{3}{|l|}{ School-composition characteristics at tracks-within-school } \\
\hline Average ESCS & $46.9^{\star \star}(5.1)$ & $46.9^{\star \star}(5.1)$ \\
\hline$\%$ students from Eastern Europe (ref = \% native students) & $0.4^{\star \star}(0.2)$ & $0.4^{\star \star}(0.2)$ \\
\hline$\%$ students from non-Islamic Asia (ref = \% native students) & $1.2^{\star \star}(0.2)$ & $1.2^{\star \star}(0.2)$ \\
\hline$\%$ students from Islamic countries (ref = \% native students) & $0.1(0.1)$ & $0.1(0.1)$ \\
\hline$\%$ students from western OECD countries (ref = \% native students) & $0.0(0.1)$ & $0.0(0.1)$ \\
\hline$\%$ students from sub-Saharan Africa (ref = \% native students) & $-0.2(0.4)$ & $-0.2(0.4)$ \\
\hline ESCS diversity & $20.0(14.0)$ & $18.8(14.0)$ \\
\hline Ethnic diversity & $-40.3^{\star \star}(11.2)$ & $-40.9^{\star \star}(11.2)$ \\
\hline \multicolumn{3}{|l|}{ Curriculum at tracks-within-school } \\
\hline Vocational (ref = general) & $-54.1^{\star \star}(4.6)$ & $-48.7^{\star \star}(4.5)$ \\
\hline Higher secondary (ref = lower) & $-0.8(4.9)$ & $-1.0(2.6)$ \\
\hline Selective admittance (ref = some selective admittance) & $18.0^{\star \star}(2.8)$ & $18.5^{\star \star}(2.8)$ \\
\hline Non-selective admittance (ref = some selective admittance) & $1.0(2.4)$ & $1.0(2.4)$ \\
\hline \multicolumn{3}{|l|}{ School characteristics } \\
\hline Teacher shortage & $-1.6(1.1)$ & $-1.6(1.1)$ \\
\hline Student/staff ratio & $0.8^{\star \star}(0.3)$ & $0.7^{\star \star}(0.3)$ \\
\hline School in city (ref = towns) & $2.7(2.7)$ & $2.6(2.7)$ \\
\hline School in rural (ref = towns) & $2.7(2.7)$ & $2.6(2.7)$ \\
\hline School size ${ }^{\star} 100$ & $0.7^{\star \star}(0.2)$ & $0.7^{\star \star}(0.2)$ \\
\hline Private dependent (ref = public school) & $-4.9(3.7)$ & $-5.3(3.7)$ \\
\hline Private independent (ref = public school) & $-6.4(5.4)$ & $-6.9(5.4)$ \\
\hline \multicolumn{3}{|l|}{ Educational system characteristics } \\
\hline Strongly stratified (ref = comprehensive) & $-16.7(14.5)$ & $-10.9(15.0)$ \\
\hline Moderately stratified (ref = comprehensive) & $-16.7(13.1)$ & $-1.1(12.7)$ \\
\hline Age of selection & $-2.3(2.6)$ & $-2.3(2.7)$ \\
\hline \multicolumn{3}{|l|}{ Interactions with educational systems } \\
\hline Parental ESCS ${ }^{\star}$ strongly stratified & $-16.5^{\star \star}(2.5)$ & $-16.4^{\star \star}(2.5)$ \\
\hline Parental ESCS ${ }^{\star}$ moderately stratified & $-16.5^{\star \star}(3.3)$ & $-16.4^{\star \star}(3.3)$ \\
\hline Average ESCS ${ }^{\star}$ strongly stratified & $19.5^{\star \star}(6.2)$ & $21.3^{\star \star}(6.2)$ \\
\hline Average ESCS ${ }^{\star}$ moderately stratified & $-11.0(8.3)$ & $-8.8(8.6)$ \\
\hline Higher secondary ${ }^{\star}$ strongly stratified & $16.3^{\star \star}(6.5)$ & $4.3(3.3)$ \\
\hline
\end{tabular}


Higher secondary ${ }^{\star}$ moderately stratified

Reproduction

Parental ESCS ${ }^{\star}$ average ESCS

Variation

Individual level

Tracks-within-school level

School level

Origin-country level

Destination-country level

Log likelihood

$$
32.7^{\star \star}(9.8)
$$

$16.7^{\star}(5.1)$

$$
-0.5(1.8)
$$

$4,516.2(89.0)$

$4,511.0(88.9)$

$917.1(82.8)$

$926.0(83.1)$

$000.0(00.0)$

$000.0(00.0)$

$444.6(91.7)$

$484.6(98.8)$

Source: PISA 2006; own computations.

\section{APPENDIX G}

Table AVII. Estimation of educational performance of first-generation migrant students from western OECD countries with different parental ESCS, in schools with different ESCS composition and track level and in different educational systems (Model 6 of Table I). The scores of the migrant students from Eastern Europe, non-Islamic Asia, Islamic countries, and sub-Saharan African countries can be obtained by changing the scores by $-8.2,+18.6,-35.3$ and -15.0 , respectively. The scores of second-generation migrant students should be changed by +9.3 , of those who use the same language as the destination country by +24.2 , and those with mixed parents by +5.8 .

\begin{tabular}{|c|c|c|c|c|c|c|c|}
\hline & Parameter & $\begin{array}{c}\text { Lowest } \\
\text { parent } \\
\text { ECSC } \\
(-4.4) \& \\
\text { vocational } \\
\& \text { lower }\end{array}$ & $\begin{array}{c}\text { Highest } \\
\text { parent } \\
\text { ECSC } \\
(3.0) \& \\
\text { vocational } \\
\& \text { lower }\end{array}$ & $\begin{array}{l}\text { Lowest } \\
\text { parent } \\
\text { ECSC } \\
(-4.4) \& \\
\text { general } \\
\& \text { lower }\end{array}$ & $\begin{array}{l}\text { Highest } \\
\text { parent } \\
\text { ECSC } \\
(3.0) \& \\
\text { general } \\
\text { \& lower }\end{array}$ & $\begin{array}{c}\text { Lowest } \\
\text { parent } \\
\text { ECSC } \\
(-4.4) \& \\
\text { general } \\
\& \text { higher }\end{array}$ & $\begin{array}{c}\text { Highest } \\
\text { parent } \\
\text { ECSC } \\
(3.0) \& \\
\text { general } \\
\text { \& higher }\end{array}$ \\
\hline Vocational & -54.1 & -54.1 & -54.1 & 0.0 & 0.0 & 0.0 & 0.0 \\
\hline Higher secondary & -0.8 & 0.0 & 0.0 & 0.0 & 0.0 & -0.8 & -0.8 \\
\hline Parent ESCS & 25.0 & -110.0 & 75.0 & -110.0 & 75.0 & -110.0 & 75.0 \\
\hline Strongly stratified & -16.7 & 0.0 & 0.0 & 0.0 & 0.0 & 0.0 & 0.0 \\
\hline School ESCS ${ }^{\star}$ strongly & 19.5 & 0.0 & 0.0 & 0.0 & 0.0 & 0.0 & 0.0 \\
\hline School ESCS ${ }^{\star}$ moderately & -11.0 & 0.0 & 0.0 & 0.0 & 0.0 & 0.0 & 0.0 \\
\hline Parent ESCS`strongly & -16.5 & 0.0 & 0.0 & 0.0 & 0.0 & 0.0 & 0.0 \\
\hline Parent ESCS ${ }^{\star}$ moderately & -16.5 & 0.0 & 0.0 & 0.0 & 0.0 & 0.0 & 0.0 \\
\hline \multirow[t]{2}{*}{ Parent ESCS ${ }^{\star}$ school ESCS } & -0.5 & -4.6 & 3.1 & -4.6 & 3.1 & -4.6 & 3.1 \\
\hline & & 198.5 & 384.6 & 246 & 438.7 & 254 & 446.7 \\
\hline
\end{tabular}

(a) Comprehensive \& lowest school ESCS (-2.07). 
(b) Comprehensive $\&$ highest school ESCS (1.64).

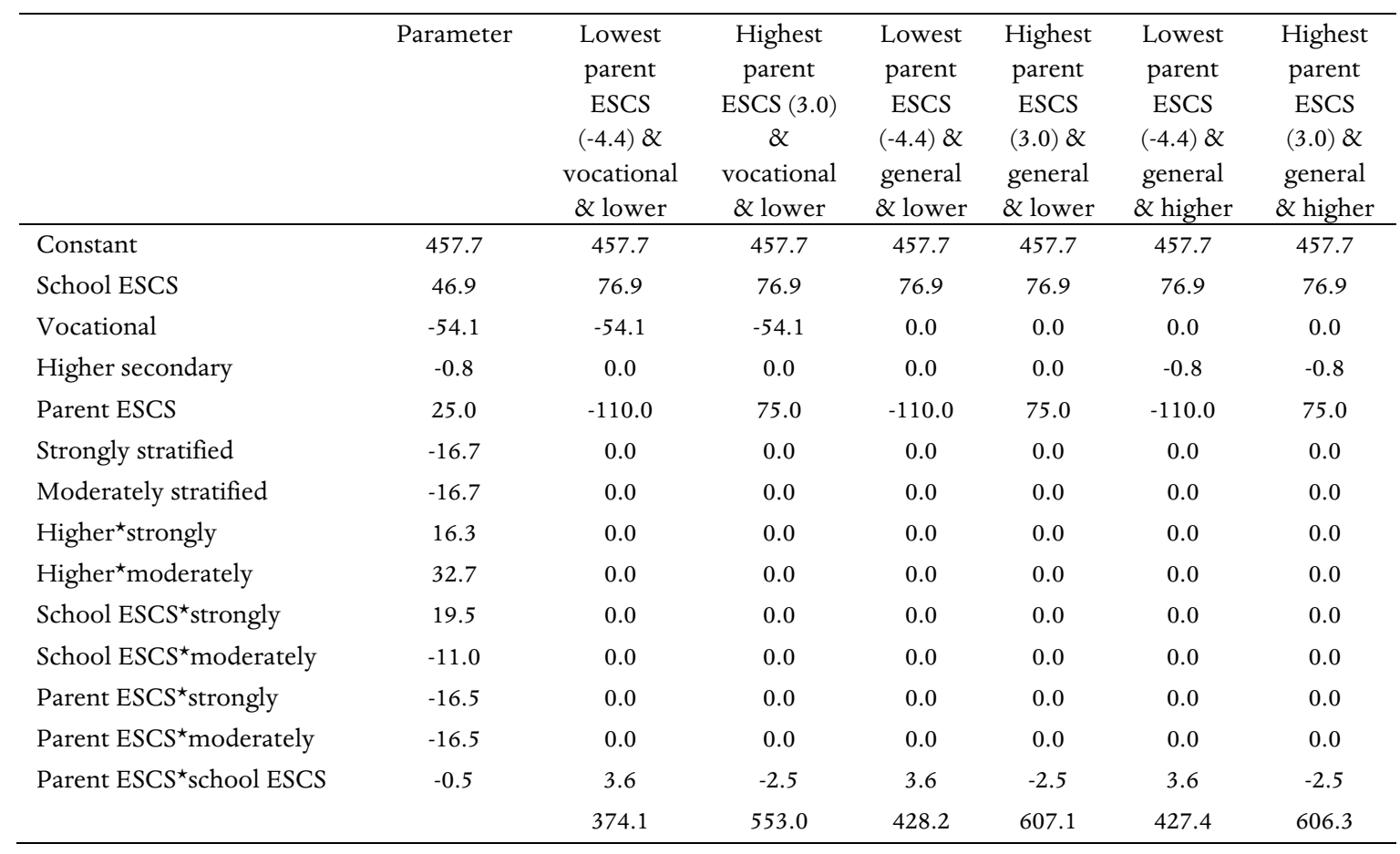

(c) Moderately stratified \& lowest school ESCS (-2.07).

\begin{tabular}{|c|c|c|c|c|c|c|c|}
\hline & Parameter & $\begin{array}{c}\text { Lowest } \\
\text { parent } \\
\text { ESCS } \\
(-4.4) \& \\
\text { vocational } \\
\text { \& lower }\end{array}$ & $\begin{array}{c}\text { Highest } \\
\text { parent } \\
\text { ESCS } \\
(3.0) \& \\
\text { vocational } \\
\text { \& lower }\end{array}$ & $\begin{array}{c}\text { Lowest } \\
\text { parent } \\
\text { ESCS } \\
(-4.4) \& \\
\text { general } \\
\text { \& lower }\end{array}$ & $\begin{array}{l}\text { Highest } \\
\text { parent } \\
\text { ESCS } \\
(3.0) \& \\
\text { general } \\
\text { \& lower }\end{array}$ & $\begin{array}{c}\text { Lowest } \\
\text { parent } \\
\text { ESCS } \\
(-4.4) \& \\
\text { general } \\
\text { \& higher }\end{array}$ & $\begin{array}{c}\text { Highest } \\
\text { parent } \\
\text { ESCS } \\
(3.0) \& \\
\text { general } \\
\text { \& higher }\end{array}$ \\
\hline Constant & 457.7 & 457.7 & 457.7 & 457.7 & 457.7 & 457.7 & 457.7 \\
\hline School ESCS & 46.9 & -97.1 & -97.1 & -97.1 & -97.1 & -97.1 & -97.1 \\
\hline Vocational & -54.1 & -54.1 & -54.1 & 0.0 & 0.0 & 0.0 & 0.0 \\
\hline Higher secondary & -0.8 & 0.0 & 0.0 & 0.0 & 0.0 & 6.2 & 6.2 \\
\hline Parent ESCS & 25.0 & -110.0 & 75.0 & -110.0 & 75.0 & -110.0 & 75.0 \\
\hline Strongly stratified & -16.7 & 0.0 & 0.0 & 0.0 & 0.0 & 0.0 & 0.0 \\
\hline Moderately stratified & -16.7 & -16.7 & -16.7 & -16.7 & -16.7 & -16.7 & -16.7 \\
\hline Higher ${ }^{\star}$ strongly & 16.3 & 0.0 & 0.0 & 0.0 & 0.0 & 0.0 & 0.0 \\
\hline Higher ${ }^{\star}$ moderately & 32.7 & 0.0 & 0.0 & 0.0 & 0.0 & 32.7 & 32.7 \\
\hline School ESCS ${ }^{\star}$ strongly & 19.5 & 0.0 & 0.0 & 0.0 & 0.0 & 0.0 & 0.0 \\
\hline School ESCS ${ }^{\star}$ moderately & -11.0 & 5.0 & 5.0 & 5.0 & 5.0 & 5.0 & 5.0 \\
\hline Parent ESCS ${ }^{\star}$ strongly & -16.5 & 0.0 & 0.0 & 0.0 & 0.0 & 0.0 & 0.0 \\
\hline Parent ESCS ${ }^{\star}$ moderately & -16.5 & 72.6 & -49.5 & 72.6 & -49.5 & 72.6 & -49.5 \\
\hline \multirow[t]{2}{*}{ Parent ESCS ${ }^{\star}$ school ESCS } & -0.5 & -4.6 & 3.1 & -4.6 & 3.1 & -4.6 & 3.1 \\
\hline & & 259.4 & 323.4 & 306.9 & 377.5 & 345.8 & 416.4 \\
\hline
\end{tabular}


(d) Moderately stratified $\&$ highest school ESCS (1.64).

\begin{tabular}{|c|c|c|c|c|c|c|c|}
\hline & Parameter & $\begin{array}{c}\text { Lowest } \\
\text { parent } \\
\text { ESCS } \\
(-4.4) \& \\
\text { vocational } \\
\text { \& lower }\end{array}$ & $\begin{array}{c}\text { Highest } \\
\text { parent } \\
\text { ESCS } \\
(3.0) \& \\
\text { vocational } \\
\text { \& lower }\end{array}$ & $\begin{array}{c}\text { Lowest } \\
\text { parent } \\
\text { ESCS } \\
(-4.4) \& \\
\text { general } \\
\text { \& lower }\end{array}$ & $\begin{array}{l}\text { Highest } \\
\text { parent } \\
\text { ESCS } \\
(3.0) \& \\
\text { general } \\
\text { \& lower }\end{array}$ & $\begin{array}{c}\text { Lowest } \\
\text { parent } \\
\text { ESCS } \\
(-4.4) \& \\
\text { general } \\
\text { \& higher }\end{array}$ & $\begin{array}{c}\text { Highest } \\
\text { parent } \\
\text { ESCS } \\
(3.0) \& \\
\text { general } \\
\text { \& higher }\end{array}$ \\
\hline Constant & 457.7 & 457.7 & 457.7 & 457.7 & 457.7 & 457.7 & 457.7 \\
\hline School ESCS & 46.9 & 76.9 & 76.9 & 76.9 & 76.9 & 76.9 & 76.9 \\
\hline Vocational & -54.1 & -54.1 & -54.1 & 0.0 & 0.0 & 0.0 & 0.0 \\
\hline Higher secondary & -0.8 & 0.0 & 0.0 & 0.0 & 0.0 & -0.8 & -0.8 \\
\hline Parent ESCS & 25.0 & -110.0 & 75.0 & -110.0 & 75.0 & -110.0 & 75.0 \\
\hline Strongly stratified & -16.7 & 0.0 & 0.0 & 0.0 & 0.0 & 0.0 & 0.0 \\
\hline Moderately stratified & -16.7 & -16.7 & -16.7 & -16.7 & -16.7 & -16.7 & -16.7 \\
\hline Higher^strongly & 16.3 & 0.0 & 0.0 & 0.0 & 0.0 & 0.0 & 0.0 \\
\hline Higher ${ }^{\star}$ moderately & 32.7 & 0.0 & 0.0 & 0.0 & 0.0 & 32.7 & 32.7 \\
\hline School ESCS ${ }^{\star}$ strongly & 19.5 & 0.0 & 0.0 & 0.0 & 0.0 & 0.0 & 0.0 \\
\hline School ESCS ${ }^{\star}$ moderately & -11.0 & -18.0 & -18.0 & -18.0 & -18.0 & -18.0 & -18.0 \\
\hline Parent ESCS ${ }^{\star}$ strongly & -16.5 & 0.0 & 0.0 & 0.0 & 0.0 & 0.0 & 0.0 \\
\hline Parent ESCS ${ }^{\star}$ moderately & -16.5 & 72.6 & -49.5 & 72.6 & -49.5 & 72.6 & -49.5 \\
\hline \multirow[t]{2}{*}{ Parent ESCS ${ }^{\star}$ school ESCS } & -0.5 & 3.6 & -2.5 & 3.6 & -2.5 & 3.6 & -2.5 \\
\hline & & 412.0 & 468.8 & 466.1 & 522.9 & 498.0 & 554.8 \\
\hline
\end{tabular}

(e) Strongly stratified \& lowest school ESCS (-2.07).

\begin{tabular}{|c|c|c|c|c|c|c|c|}
\hline & Parameter & $\begin{array}{c}\text { Lowest } \\
\text { parent } \\
\text { ESCS } \\
(-4.4) \& \\
\text { vocational } \\
\text { \& lower }\end{array}$ & $\begin{array}{c}\text { Highest } \\
\text { parent } \\
\text { ESCS } \\
(3.0) \& \\
\text { vocational } \\
\text { \& lower }\end{array}$ & $\begin{array}{c}\text { Lowest } \\
\text { parent } \\
\text { ESCS } \\
(-4.4) \& \\
\text { general } \\
\text { \& lower }\end{array}$ & $\begin{array}{c}\text { Highest } \\
\text { parent } \\
\text { ESCS } \\
(3.0) \& \\
\text { general } \\
\text { \& lower }\end{array}$ & $\begin{array}{c}\text { Lowest } \\
\text { parent } \\
\text { ESCS } \\
(-4.4) \& \\
\text { general } \\
\text { \& higher }\end{array}$ & $\begin{array}{c}\text { Highest } \\
\text { parent } \\
\text { ESCS } \\
(3.0) \& \\
\text { general } \\
\text { \& higher }\end{array}$ \\
\hline Constant & 457.7 & 457.7 & 457.7 & 457.7 & 457.7 & 457.7 & 457.7 \\
\hline School ESCS & 46.9 & -97.1 & -97.1 & -97.1 & -97.1 & -97.1 & -97.1 \\
\hline Vocational & -54.1 & -54.1 & -54.1 & 0.0 & 0.0 & 0.0 & 0.0 \\
\hline Higher secondary & -0.8 & 0.0 & 0.0 & 0.0 & 0.0 & -0.8 & -0.8 \\
\hline Parent ESCS & 25.0 & -110.0 & 75.0 & -110.0 & 75.0 & -110.0 & 75.0 \\
\hline Strongly stratified & -16.7 & -16.7 & -16.7 & -16.7 & -16.7 & -16.7 & -16.7 \\
\hline Moderately stratified & -16.7 & 0.0 & 0.0 & 0.0 & 0.0 & 0.0 & 0.0 \\
\hline Higher ${ }^{\star}$ strongly & 16.3 & 0.0 & 0.0 & 0.0 & 0.0 & 16.3 & 16.3 \\
\hline Higher ${ }^{\star}$ moderately & 32.7 & 0.0 & 0.0 & 0.0 & 0.0 & 0.0 & 0.0 \\
\hline School ESCS`strongly & 19.5 & -40.4 & -40.4 & -40.4 & -40.4 & -40.4 & -40.4 \\
\hline School ESCS ${ }^{\star}$ moderately & -11.0 & 0.0 & 0.0 & 0.0 & 0.0 & 0.0 & 0.0 \\
\hline Parent ESCS`strongly & -16.5 & 72.6 & -49.5 & 72.6 & -49.5 & 72.6 & -49.5 \\
\hline Parent ESCS ${ }^{\star}$ moderately & -16.5 & 0.0 & 0.0 & 0.0 & 0.0 & 0.0 & 0.0 \\
\hline \multirow[t]{2}{*}{ Parent ESCS ${ }^{\star}$ school ESCS } & -0.5 & -4.6 & 3.1 & -4.6 & 3.1 & -4.6 & 3.1 \\
\hline & & 214.0 & 278.0 & 261.5 & 332.1 & 277.0 & 347.6 \\
\hline
\end{tabular}




\begin{tabular}{|c|c|c|c|c|c|c|c|}
\hline & Parameter & $\begin{array}{c}\text { Lowest } \\
\text { parent } \\
\text { ESCS } \\
(-4.4) \& \\
\text { vocational } \\
\text { \& lower } \\
\end{array}$ & $\begin{array}{c}\text { Highest } \\
\text { parent } \\
\text { ESCS } \\
(3.0) \& \\
\text { vocational } \\
\text { \& lower } \\
\end{array}$ & $\begin{array}{l}\text { Lowest } \\
\text { parent } \\
\text { ESCS } \\
(-4.4) \& \\
\text { general } \\
\text { \& lower } \\
\end{array}$ & $\begin{array}{l}\text { Highest } \\
\text { parent } \\
\text { ESCS } \\
(3.0) \& \\
\text { general } \\
\text { \& lower }\end{array}$ & $\begin{array}{l}\text { Lowest } \\
\text { parent } \\
\text { ESCS } \\
(-4.4) \& \\
\text { general } \\
\text { \& higher }\end{array}$ & $\begin{array}{l}\text { Highest } \\
\text { parent } \\
\text { ESCS } \\
(3.0) \& \\
\text { general } \\
\text { \& higher }\end{array}$ \\
\hline Constant & 457.7 & 457.7 & 457.7 & 457.7 & 457.7 & 457.7 & 457.7 \\
\hline School ESCS & 46.9 & 76.9 & 76.9 & 76.9 & 76.9 & 76.9 & 76.9 \\
\hline Vocational & -54.1 & -54.1 & -54.1 & 0.0 & 0.0 & 0.0 & 0.0 \\
\hline Higher secondary & -0.8 & 0.0 & 0.0 & 0.0 & 0.0 & -0.8 & -0.8 \\
\hline Parent ESCS & 25.0 & -110.0 & 75.0 & -110.0 & 75.0 & -110.0 & 75.0 \\
\hline Strongly stratified & -16.7 & -16.7 & -16.7 & -16.7 & -16.7 & -16.7 & -16.7 \\
\hline Moderately stratified & -16.7 & 0.0 & 0.0 & 0.0 & 0.0 & 0.0 & 0.0 \\
\hline Higher^strongly & 16.3 & 0.0 & 0.0 & 0.0 & 0.0 & 16.3 & 16.3 \\
\hline Higher ${ }^{\star}$ moderately & 32.7 & 0.0 & 0.0 & 0.0 & 0.0 & 0.0 & 0.0 \\
\hline School ESCS ${ }^{\star}$ strongly & 19.5 & 32.0 & 32.0 & 32.0 & 32.0 & 32.0 & 32.0 \\
\hline School ESCS ${ }^{\star}$ moderately & -11.0 & 0.0 & 0.0 & 0.0 & 0.0 & 0.0 & 0.0 \\
\hline Parent ESCS ${ }^{\star}$ strongly & -16.5 & 72.6 & -49.5 & 72.6 & -49.5 & 72.6 & -49.5 \\
\hline Parent ESCS ${ }^{\star}$ moderately & -16.5 & 0.0 & 0.0 & 0.0 & 0.0 & 0.0 & 0.0 \\
\hline \multirow[t]{2}{*}{ Parent ESCS ${ }^{\star}$ school ESCS } & -0.5 & 3.6 & -2.5 & 3.6 & -2.5 & 3.6 & -2.5 \\
\hline & & 462.0 & 518.8 & 516.1 & 572.9 & 531.6 & 588.4 \\
\hline
\end{tabular}

JAAP DRONKERS studied sociology at the Vrije Universiteit Amsterdam. He has been Associate Professor of the Sociology of Education and Empirical Sociology at the Catholic University of Brabant in Tilburg (1986-90); and Chair in Educational Sciences (1990-99), and Chair in Empirical Sociology (1999-2001) both at the University of Amsterdam. From October 2001 until December 2009 he was Professor of Social Stratification and Inequality at the European University Institute (EUI) in Florence. Since December 2009 he has been the holder of the chair in international comparative research on educational performance and social inequality at Maastricht University. Correspondence: j.dronkers@maastrichtuniversity.nl

ROLF VAN DER VELDEN is professor at Maastricht University and programme director of Education and Occupational Career at the Research Centre for Education and the Labour Market (ROA). He supervised several (inter)national studies on the transition from school to work and is presently coordinating the international REFLEX project. He is a board member of the Network Transition in Youth and member of several research associations in the field of social stratification, education and the labour market. In 1983 he finished his studies in sociology at the University of Groningen. From 1983 till 1990 he worked at the Institute for Educational Research in Groningen, where he held the position of Head of the Division of Labour Market Research.

ALLISON DUNNE is now a consultant with GHK International, Brussels, Belgium. Allison is from Dublin, Ireland and completed her undergraduate studies at the Queen's University Belfast, Northern Ireland. Allison successfully defended her PhD (Divided Lines: examining the relative importance of between- and within-school differentiation during lower secondary education) in May 2010 at the European University Institute, Florence, Italy. Allison's broad research interests are in social stratification and comparative sociology. 